Summer 2000

\title{
A Cause Worth Quitting for? The Conflict Between Professional Ethics and Individual Rights in Discriminatory Treatment of Corporate Counsel
}

Rachel S. Arnow Richman

Temple University Beasley School of Law

Follow this and additional works at: https://www.repository.law.indiana.edu/ilj

Part of the Legal Ethics and Professional Responsibility Commons, and the Legal Profession

Commons

\section{Recommended Citation}

Arnow Richman, Rachel S. (2000) "A Cause Worth Quitting for? The Conflict Between Professional Ethics and Individual Rights in Discriminatory Treatment of Corporate Counsel," Indiana Law Journal: Vol. 75 :

Iss. 3 , Article 4.

Available at: https://www.repository.law.indiana.edu/ilj/vol75/iss3/4

This Article is brought to you for free and open access by the Law School Journals at Digital Repository @ Maurer Law. It has been accepted for inclusion in Indiana Law Journal by an authorized editor of Digital Repository @ Maurer Law. For more information, please contact rvaughan@indiana.edu.

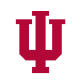

JEROME HALL LAW LIBRARY

INDIANA UNIVERSITY

Maurer School of Law
Bloomington 


\title{
A Cause Worth Quitting for? The Conflict Between Professional Ethics and Individual Rights in Discriminatory Treatment of Corporate Counsel ${ }^{\dagger}$
}

\author{
RACHEL S. ARNOW RICHMAN*
}

\section{INTRODUCTION}

The last several decades have witnessed an increase ${ }^{l}$ in the reliance on in-house corporate legal departments, as well as a concomitant growth in the visibility and status of in-house attorneys. ${ }^{2}$ It is now routine for companies to retain sophisticated legal work to be performed inside, ${ }^{3}$ and for in-house attorneys ${ }^{4}$ to become integrated and influential actors within their corporate environments. ${ }^{5}$ For all of the advantages

† Copyright 2000 by Rachel S. Arnow Richman.

* Honorable Abraham L. Freedman Fellow, Temple University Beasley School of Law. J.D., 1995, Harvard Law School. I am grateful for the insightful comments and heartfelt encouragement of my current and former colleagues Marina Angel, Clay Beery, Theresa Glennon, Rick Greenstein, Alicia Kelly, Courtney Lytle, Finbarr McCarthy, Eleanor Myers, Anthony Niedwiecki, and Frank Snyder. Special thanks to Jennifer Malcarney, John Nocito, and Jennifer Falgie for their diligent research assistance and to Temple University School of Law for its support of this project.

1. The number of lawyers working in-house increased by $40 \%$ between 1970 and 1980 and by $30 \%$ between 1980 and 1991. See Mary C. Daly, The Cultural, Ethical, and Legal Challenges in Lawyering for a Global Organization: The Role of the General Counsel, 46 EMORY L.J. 1057, 1059 n.5 (1997) (citing BARBARA A. CURRAN ET AL., THE LAWYER STATISTICAL REPORT: A STATISTICAL PROFILE OF THE U.S. LEGAL PROFESSION IN THE 1980S 19 (1985), and BARBARA A. CURRAN ET AL., THE LAWYER STATISTICAL REPORT: THE U.S. LEGAL PROFESSION N THE 1990S 7 (1994)); see also Abram Chayes \& Antonia H. Chayes, Corporate Counsel and the Elite Law Firm, 37 STAN. L. REv. 277, 277 n.1 (1985) (citing COMM. ONTHE CORPORATE LAW DEP'TS OF THE BAR OF THE CITY OF N.Y.\& ARTHUR YOUNG \&CO., NATIONAL SURVEY OF CORPORATE LAW COMPENSATION \& ORGANZATION PRACTICES (6th ed. 1983) [hereinafter ARTHUR YOUNG SURVEY]); Ted Schneyer, Professionalism and Public Policy: The Case of House Counsel, 2 GEO. J. LEgal ETHICS 449, 449 n.4 (1988) (citing ARTHUR YOUNG SURVEY, supra); Sally R. Weaver, Ethical Dilemmas of Corporate Counsel: A Structural and Contextual Analysis, 46 EMORY L.J. 1023, 1031 n.30 (1997).

2. Once considered second-tier professionals, in-house counsel now rival their law firm counterparts in status, experience, and compensation. See Carl D. Liggio, The Changing Role of Corporate Counsel, 46 EMORY L.J. 1201, 1203-07 (1997) (describing trends in recruitment and compensation of in-house counsel); Robert Eli Rosen, The Inside Counsel Movement, Professional Judgment and Organizational Representation, 64 IND. L.J. 479, 479 (1989) (noting increased competition in recruitment of in-house counsel and increased recognition of in-house counsel within profession generally); see also discussion infra Part III.B.2.

3. See Liggio, supra note 2, at 1205-06 (summarizing statistics on percentages and type of work performed in-house); see also Daly, supra note 1, at 1060 (noting expansion in responsibilities of in-house counsel as corporations redirect work inside to avoid growing costs associated with obtaining outside legal services).

4. This Article uses the terms "in-house attorney," "in-house counsel," and "corporate counsel" interchangeably to refer to attorneys employed by a sole client-employer.

5. In addition to providing the usual legal services, the in-house attorney may fill the roles 
this trend provides, both to companies ${ }^{6}$ and the lawyers they employ, the retention of in-house attorneys creates special problems in terms of the expectations and regulations that govern attorney-client relationships. Both from an ethical perspective and through the lens of substantive law, the issue of what legal rules control attorney conduct, already the subject of wide debate, ${ }^{7}$ becomes increasingly complex when forced to take account of the complicated and sometimes conflicting responsibilities that the in-house attorney assumes. ${ }^{8}$ Of special importance to the resolution of any of these questions is how one characterizes the attorney's role, whether primarily as employee or as client fiduciary, and consequently her obligations both to others and herself.

One area of particular significance to those attorneys employed as corporate counsel, which as of yet has been given little scholarly attention, ${ }^{9}$ is the tension between the Model Rules of Professional Conduct that govern attorney ethics ${ }^{10}$ and the rights conferred by Title VII of the 1964 Civil Rights Act." While the latter

of corporate officer, manager, board member, and business decisionmaker. See Weaver, supra note 1, at 1027; infra Part III.B.2. Of course, in all cases, in-house counsel also assumes the role of an employee. The implications of this diversification of the in-house attorney's function are discussed infra Part III.B.2.

6. From the perspective of corporate clients, the decision to utilize in-house counsel serves its interests in maximizing access to legal representation and counseling while minimizing the financial and transactional costs associated with hiring and managing private legal counsel. See Alison B. Brotman \& John H. Ogden, In-House Counsel: Managing the Split Personality, ACCA DOCKET, May-June 1995, at 34, 34 (1995) (noting that chief advantage of retention of in-house counsel is counsel's daily contact with clients, which increases counsel's ability to provide well-informed and hence cost-effective advice); Daly, supra note 1, at 1060-61 (discussing financial advantages to reliance on in-house counsel); infra Parts III.B.2, III.C.

7. See, e.g., Special Issue, Institutional Choices in the Regulation of Lawyers, 65 FORDHAM L. REV. 33 (1996); David B. Wilkins, Who Should Regulate Lawyers?, 105 HARV. L. REV. 799, 804-18 (1992) (describing various existing systems for enforcement of lawyers' professional obligations and outlining arguments in favor of differing regimes).

8. With respect to in-house counsel, both scholars and judges have struggled with how to balance the in-house attorney's competing obligations and resolve the tension between distinct bodies of law in addressing fundamental legal questions. See, e.g., United States Steel Corp. v. United States, 569 F. Supp. 870 (Ct. Int'1 Trade 1983) (addressing whether in-house counsel may have access to confidential information protected by court order to the same extent as outside lawyers), modified, 578 F. Supp. 415 (Ct. Int'l Trade 1983); Grace M. Giesel, The Legal Advice Requirement of the Attorney-Client Privilege: A Special Problem for InHouse Counsel and Outside Attorneys Representing Corporations, 48 MERCER L. REV. 1169 (1997) (addressing circumstances under which communications to in-house counsel should be considered protected by the attorney-client privilege); discussion infra Part IV.A.1 (summarizing conflicting decisions as to whether in-house counsel may sue at common law for wrongful discharge).

9. The question has been briefly considered in at least two articles. See Nancy J. Moore, Conflicts of Interest for In-House Counsel: Issues Emerging from the Expanding Role of the Attorney-Employee, 39 S. TEX. L. REV. 497, 543 (1998) (concluding that counsel subject to discrimination while employed might be required to resign at the request of the client in order to pursue legal claims); Weaver, supra note 1, at 1048.

10. MODEL RULES OF PROFESSIONAL CONDUCT (1998) [hereinafter MOdel RULES]

11. Civil Rights Act of 1964,42 U.S.C. $\$ \$ 2000 \mathrm{e}-1$ to -17 (1994). 
establishes a federal cause of action against one's employer for unlawful discrimination, the former strictly limits the extent to which an attorney may pursue interests adverse to a client or disclose information about the representation of a client to third parties. Suppose, for instance, that a junior African-American in-house attorney is denied a promotion within his company's legal department in favor of a white attorney with less experience. Or suppose a female in-house attorney is subjected on several occasions to unwanted sexual advances by a male senior manager. Were the victim in either of these scenarios a regular employee, $\mathrm{she}^{\mathrm{i2}}$ would be entitled to bring a Title VII claim against her employer for unlawful discrimination. ${ }^{13}$ Further, the statute would protect her from retaliatory behavior by the employer taken in response to her exercise of federal rights, and the employer would consequently be prohibited from terminating or otherwise adversely affecting the attorney's employment based on her claim. ${ }^{14}$

In the in-house counsel context, by contrast, the nature and limits of statutory protection are highly complicated. Whereas a regular employee faces no external constraints in bringing a discrimination suit, the in-house attorney is arguably prohibited by the Model Rules from initiating such a claim as it is clearly adverse to the interests of her client. ${ }^{15}$ Moreover, it is unclear what information, if any, may be pleaded in the attorney's complaint or ultimately utilized as evidence in her suit since all information pertaining to the claim relates to the representation of a client and may consequently be deemed confidential under the Model Rules. ${ }^{16}$ Finally, and perhaps most importantly, the Model Rules and background common law grant clients the inviolate ability to sever the attorney-client relationship at any time and for any reason. ${ }^{17}$ Thus, it is uncertain whether the in-house attorney may avail herself of the protection afforded by the anti-retaliation provision of the statute in the likely event that the client-employer wishes to terminate her as a result of her claim.

For these reasons, significant questions arise as to the relationship between the Model Rules and Title VII ${ }^{18}$ in situations where an in-house attorney is subject to unlawful employment discrimination. While several cases have addressed the viability of a cause of action by an attorney terminated for allegedly discriminatory

12. For purposes of convenience, the author has elected to use the feminine pronoun when referring to a hypothetical in-house attorney subject to discrimination. Obviously the analysis offered here applies equally to male in-house attorneys.

13. See infra Part I.A. (identifying the causes of action available under Title VII).

14. See infra Part I.A. (explaining the scope of protection afforded by the anti-retaliation provision of Title VII).

15. See infra Part 1.B.1. (discussing applicable conflicts of interest rules).

16. See infra Part I.B.2. (discussing applicable confidentiality rules).

17. See infra Part I.B.1. (discussing mandatory withdrawal regime).

18. Similar issues arise in the context of in-house attorneys subject to discrimination cognizable under federal statutes other than Title VII, including the Americans with Disabilities Act ("ADA") and the Age Discrimination in Employment Act ("ADEA"), which confer comparable rights on other protected classes of employees. See Americans with Disabilities Act, 42 U.S.C.A. $\$ \S 12101-12213$ (West 1999); Age Discrimination in Employment Act, 29 U.S.C.A. $\$ \S 621-634$ (West 1999). The analysis of the attorney's ability to redress discrimination under those acts would be virtually identical to the analysis supplied here. This Article, however, focuses uniquely on the provisions of Title VII. 
reasons, ${ }^{19}$ few cases involve the means of relief available to employed in-house attorneys, ${ }^{20}$ and none have directly confronted the inevitable conflict posed by the Model Rules in this context. This Article explores and seeks to resolve these important issues. Part I sets the groundwork for the analysis by outlining the privileges and constraints that apply to and govern corporate counsel. Part II outlines and critiques current case law that concerns, but fails sufficiently to confront, the inherent conflict between employee rights and attorney ethics resulting from discrimination against in-house counsel, and consequently fails to provide the necessary practical guidance to counsel who find themselves in this professional dilemma. Part III more thoroughly explores the nature of the legal conflict by examining the roots and implications of the rules and roles imposed on lawyers and concludes that existing restraints on attorney conduct are insufficiently flexible to accommodate lawyers' increased and changing responsibilities as in-house counsel and wrongly permit clients to escape their responsibilities as employers. Finally, Part IV proposes a doctrinal solution that would permit a corporate attorney in most circumstances to exercise her right to be free from workplace discrimination, including the corresponding right to escape retaliatory treatment, while still recognizing, and in large part preserving, the client-employer's expectations of loyalty and confidentiality in its relationship with its counsel.

\section{THE COMPETING LEGAL REGIMES}

The equal employment opportunity rights and attendant responsibilities of corporate attorneys are set forth in two distinct bodies of doctrine: Title VII of the Federal Civil Rights Act of $1964^{21}$ and the Model Rules of Professional Responsibility, as adopted and applied by the state court systems. ${ }^{22}$ The former

19. Courts have consistently held that attorneys may pursue Title VII claims against the firms that employ them. See, e.g., Ezold v. Wolf, Block, Schorr, Soliscohen 983 F.2d 509 (3d Cir. 1993) (discussing lawsuit by associate attorney against law firm alleging discriminatory failure to admit plaintiff to partnership); Masterson v. LaBrum and Doak, 846 F. Supp. 1224 (E.D. Pa. 1993). Courts have also held that in-house attorneys may pursue post-termination Title VII claims against corporate employers. See, e.g., Douglas v. DynMcDermott Petroleum Operations Co., 144 F.3d 364 (5th Cir. 1998); Golightly-Howell v. Oil, Chemical \& Atomic Workers Int'l Union, 806 F. Supp. 921 (D. Colo. 1992); Rand v. CF Indus., Inc., 797 F. Supp. 643 (N.D. Ill. 1992); Graham v. Texasgulf, Inc., 662 F. Supp. 1451 (D. Conn. 1987).

20. See, e.g., Douglas, 144 F.3d at 371; Jones v. Flagship Int'l, 793 F.2d 714 (5th Cir. 1986); Terry v. Gallegos, 926 F. Supp. 679 (W.D. Tenn. 1996); Verney v. Pennsylvania Turnpike Comm'n, 903 F. Supp. 826 (M.D. Pa. 1995); see generally infra Part II.A-B.

21. 42 U.S.C. $\S \S 2000 \mathrm{e}-1$ to -17 (1994).

22. The Model Rules, as promulgated by the American Bar Association, are not legally binding, however, they constitute the majority approach to professional regulation. As of fall 1999 , more than 40 states and the District of Columbia had adopted all or a significant portion of the Model Rules, and others were in the process of so doing. See STEPHEN GILLERS \& ROY D. SIMONS, REGULATION OF LAWYERS: STATUTES AND STANDARDS at xxiv (2000); see also 2 GEOFFREY C. HAZARD, JR. \& W. WILlIAM HODES, THELAW OF LAWYERING: A HANDBOOK ON THE MODEL RULES OF PROFESSIONAL CONDUCT § AP4:101 (2d ed. supp. 1994) (noting that some states who have declined to adopt the Model Rules have relied heavily on them in adopting their own state codes). 
governs "employees"; and the latter, "attorneys." These bodies of law, neither of which directly contemplate their applicability to in-house attorneys or their relationship to one another, have fundamentally different purposes and effects which create significant uncertainty as to the extent to which in-house counsel may oppose unlawful discrimination in the workplace. The following section establishes the basis for this conflict by providing an introduction to the two competing sources of doctrinal law.

\section{A. The Rights: Freedom from Retaliation Under Title VII of the Civil Rights Act}

Title VII of the Civil Rights Act of 1964 outlaws discriminatory treatment in the workplace and grants aggrieved employees, including attorneys, ${ }^{23}$ a cause of action against employers who engage in discriminatory behavior. Under the Act, it is considered an unlawful employment practice to refuse to hire, discharge, or "otherwise . . . discriminate against any individual" on the basis of race, color, religion, sex, or national origin. ${ }^{24}$ It is also unlawful for an employer to discriminate against any employee because that individual has filed a charge against the employer, opposed an unlawful employment practice, or has assisted in any investigation or proceeding regarding an alleged violation. ${ }^{25}$ Thus, the statute creates a cause of action whereby employees may oppose discriminatory practices and, significantly, it protects the right to engage in oppositional conduct by insulating employees from retaliatory behavior by the employer. ${ }^{26}$

To sustain a prima facie case of retaliation, the employee need merely show that she engaged in good faith in conduct protected under the statute, that she suffered an adverse employment action, and that the action was causally connected to her act of opposition. ${ }^{27}$ The burden then shifts to the employer to offer a nondiscriminatory rationale for its action, which the employee may try to rebut as pretextual. ${ }^{28}$ The

23. See Ezold, 983 F.2d at 509; Masterson, 846 F. Supp. at 1224.

24. 42 U.S.C. $\S 2000 \mathrm{e}-2(\mathrm{a})(1)(1994)$.

25. See id. $\S 2000 \mathrm{e}-3(\mathrm{a})$.

26. This section generally refers to "oppositional" conduct as opposed to "participatory" conduct, which is also protected under the anti-retaliation provision. A suit for retaliation for participatory conduct would proceed under the same doctrinal structure applicable to oppositional conduct-retaliation claims. However, because the conduct at issue in this Article involves opposition to discriminatory treatment of in-house counsel, the term oppositional conduct will be used here. For a discussion of the distinctions between oppositional and participatory conduct, see generally 1 BARBARA LINDEMANN \& PAUL GrosSMAN, EMPLOYMENT DISCRIMINATION LAW 651-65 (3d ed. 1996).

27. See Holland v. Jefferson Nat'l Life Ins. Co., 883 F.2d 1307, 1313 (7th Cir. 1989); Wrighten v. Metropolitan Hosps., Inc., 726 F.2d 1346, 1354 (9th Cir. 1984); Grant v. Bethlehem Steel Corp., 622 F.2d 43, 46 (2d Cir. 1980). See generally LINDEMANN \& GROSSMAN, supra note 26, at 672-78 (describing the elements of a retaliation claim).

28. See Holland, 883 F.2d at 1313; Wrighten, 726 F.2d at 1354; Grant, 622 F.2d at 46. See generally LINDEMANN \& GROSSMAN, supra note 26, at 672-78. This burden of proof structure is comparable to the three-part framework for proving and analyzing disparate treatment cases. See St. Mary's Honor Ctr. v. Hicks, 509 U.S. 502 (1993); Texas Dep't of Community Affairs 
creation of this cause of action, and the relative ease with which a prima facie case can be established, serve as a safeguard in effectuating the legislation's overriding purposes of eliminating and preventing workplace discrimination. ${ }^{29}$ Because the dominant background rule continues to be employment at will, ${ }^{30}$ the absence of a statutory prohibition against retaliation would render the primary cause of action for discrimination meaningless, as employers would remain free to stifle oppositional conduct by terminating or otherwise altering the working conditions of its employees. ${ }^{31}$ The anti-retaliation provision, therefore, enables employees to meaningfully oppose unlawful conduct by eliminating the employer's otherwise unbridled power to terminate the employment relationship.

Notably, the protection afforded by the anti-retaliation clause is far-reaching, both in terms of the range of employees who might invoke its protection and the limitations placed on employers who might otherwise respond adversely to an

v. Burdine, 450 U.S. 248 (1981); McDonnell Douglas Corp. v. Green, 411 U.S. 792 (1973).

29. "From the outset, Congress has said that '[t]he purpose of [Title VII] is to eliminate, through the utilization of formal and informal remedial procedures, discrimination in employment based on race, color, religion or national origin." TWA, Inc. v. Hardison, 432 U.S. 63, 71 n.6 (quoting H.R. REP. No. 914, at 26 (1963), reprinted in 1964 U.S.C.C.A.N. 2355,2401 ); see also EEOC v. Shell Oil Co., 466 U.S. 54,77 (1984) ("The dominant purpose of [Title VII] . . . is to root out discrimination in employment.").

30. See Adair v. United States, 208 U.S. 161, 174-75 (1908) ("The right of an employ[ee] to quit the service of the employer, for whatever reason, is the same as the right of the employer, for whatever reason, to dispense with the services of such employ[ee]."). It should be noted, however, that most jurisdictions recognize a growing number of exceptions to the common law doctrine, including implied contracts (based upon oral promises, handbooks, or the parties' course of dealing); violation of public policy; and the implied covenant of good faith and fair dealing. For a discussion of these exceptions and their eroding effect on the atwill doctrine, see, for example, Deborah L. Markowitz, The Demise of At-Will Employment and the Public Employee Conundrum, 27 URB. LAW. 305 (1995) (exploring the law's growing trend to limit an employer's ability to terminate at will); Cortlan H. Maddux, Note, EMPLOYERS BEWARE! The Emerging Use of Promissory Estoppel as an Exception to Employment At Will, 49 BAYLOR L. REV. 197 (1997) (exploring employees' increasing use of promissory estoppel to alter the at-will relationship and seek relief for wrongful discharge). See generally Maureen S. Binetti et al., The Employment-At-Will Doctrine: Have Its Exceptions Swallowed the Rule?, in WRONGFUL TERMINATION ClAIMS 1999, at 441 (PLI Litig. Course Handbook Series No. H-600, 1999) (outlining common implied limitations on an employer's discretion to terminate at-will employees); Mark E. Brossman \& Laurie C. Malkin, Beyond the Implied Contract: The Public Policy Exception, The Implied Covenant of Good Faith and Fair Dealing, and Other Limitations on an Employer's Discretion in the At-Will Setting, in WRONGFUL TERMINATION ClAIMS 1999, supra, at 587 (same). But see, e.g., Joseph Z. Fleming, Labor and Employment Law: Recent Developments-At-Will Termination of Employment Has Not Been Terminated, 20 Nova L. REV. 437 (1995) (recognizing recent judicial rulings and trends which have sustained the doctrine of employment-at-will in the face of growing statutory regulation of the work place).

31. See Jones, 793 F.2d at 726 ("[S]ince the enforcement of Title VII rights necessarily depends on the ability of individuals to present their grievances without the threat of retaliatory conduct by their employers, rigid enforcement of [the retaliatory discharge provision] is required."); Hanson v. Hoffmann, 628 F.2d 42, 52 (D.C. Cir. 1980); Pettway v. American Cast Iron Pipe Co., 411 F.2d 998, 1006 n.18 (5th Cir. 1969). 
employee's invocation of statutory rights. An employee may deserve protection under the statute simply because she makes a complaint to a supervisor or invokes an internal grievance procedure ${ }^{32}$ even if she never initiates legal action. ${ }^{33}$ The subject of the complaint need not be the victim herself, and retaliation is cognizable even if it occurs following opposition to the treatment of co-workers or general office policies. ${ }^{34}$ Most importantly, retaliation claims are recognized even where the conduct complained of by the employee is ultimately found to have been lawful. ${ }^{35}$ The employee need only have a reasonable and good faith belief that the conduct he or she opposed was an unlawful employment practice. ${ }^{36}$

That is not to say that all conduct in opposition to allegedly discriminatory behavior is protected. Courts have recognized that the manner in which an employee engages in oppositional conduct may become so disruptive and debilitating to the employer's business as to render the conduct unprotected under the statute. ${ }^{37}$ Where such a

32. See Sumner v. United States Postal Serv., 899 F.2d 203, 209 (2d Cir. 1990); Sias v. City Demonstration Agency, 588 F.2d 692, 694-96 (9th Cir. 1978).

33. See Hearn v. R.R. Donnelley \& Sons Co., 460 F. Supp. 546, 548 (N.D. Ill. 1978) ("[Title VII] was not intended to penalize employees who seek to improve the conditions of the work place through informal methods rather than entangling the employer in a potentially lengthy and expensive Commission proceeding."). For a discussion of the scope of protected activity under Title VII, see generally LINDEMANN \& GROSSMAN, supra note 26, 658-67; Melissa A. Essary \& Terence D. Friedman, Retaliation Claims Under Title VII, the ADEA, and the ADA: Untouchable Employees, Uncertain Employers, Unresolved Courts, 63 Mo. L. REV. 115, 121-32 (1998); Douglas E. Ray, Title VII Retaliation Cases: Creating a New Protected Class, 58 U. PITT. L. Rev. 405, 409-13 (1997).

34. See, e.g., Kachmar v. Sungard Data Systems, Inc., 109 F.3d 173, 177 (3d Cir. 1997) (treating in-house counsel-plaintiff's conduct as "protected" where counsel discussed with upper management the EEO implications of personnel policies, including management's treatment of women); Robinson v. SEPTA, 982 F.2d 892, 896 (3d Cir. 1993) (finding that employee's letter to congressman complaining about harassment of black employees was oppositional conduct within the meaning of Title VII); EEOC v. Crown Zellerbach Corp., 720 F.2d 1008, 1014 (9th Cir. 1983) (finding that employee's letter to employer's customer protesting an affirmative action award by employer was a "statutorily protected expression of 'opposition"'); Federoff v. Walden, No. C-2-78-181, 1978 WL 34 *6 (S.D. Ohio Mar. 24, 1978) (finding that employee's support of a co-worker's EEOC claim was protected from an employer's retaliation under Title VII).

35. See Holland, 883 F.2d at 1314-16; Crown Zellerbach, 720 F.2d at 1013 ("[O]pposition clause protection will be accorded whenever the opposition is based on a 'reasonable belief that the employer has engaged in an unlawful employment practice."); Parker v. Baltimore \& Ohio R.R. Co., 652 F.2d 1012, 1020 (D.C. Cir. 1981).

36. See Manoharan v. Columbia Univ. College of Physicians \& Surgeons, 842 F.2d 590, 593 (2d Cir. 1988); Payne v. McLemore's Wholesale \& Retail Stores, 654 F.2d 1130, 1140 (5th Cir. 1981). 1980).

37. See, e.g., Rosser v. Laborers' Int'l Union, Local No. 438, 616 F.2d 221, 223 (5th Cir.

There may arise instances where the employee's conduct in protest of an unlawful employment practice so interferes with the performance of his job that it renders him ineffective in the position for which he was employed. In such a case, his conduct, or form of opposition, is not covered by [Title VII's] $\S$ 704(a).

Id. 
defense is alleged, the court balances the statute's purpose and the need to protect individual rights against the employer's need to maintain a productive work environment to determine whether the manner of the employee's opposition is reasonable. ${ }^{38}$ This test, however, has been narrowly applied to exclude only a limited range of activity in particular circumstances. The mere assertion that an employee's oppositional conduct was "disloyal" toward the employer has been held insufficient to justify depriving the employee of the statute's protection..$^{39}$ Rather, conduct is excluded only where the manner in which the employee engages in protest goes beyond oppositional behavior and can itself be considered a legitimate basis for termination. ${ }^{40}$ Thus, illegal conduct, conduct that consciously seeks to sabotage the employer's enterprise, or conduct that causes an employee to neglect job responsibilities or unduly disrupt co-workers in performing their duties may fall outside the statute's protection. ${ }^{41}$

The definition of adverse employment action is also broad. The acts of employers that may constitute retaliatory behavior comprise the range of behaviors associated with discriminatory treatment, including termination of employment, failure to hire or promote, imposition of or failure to grant leave, forced transfers, and changes in benefits or compensation. ${ }^{42}$ Some courts have held that even actions that have only

38. See Rollins v. Florida Dep't of Law Enforcement, 868 F.2d 397, 401 (11th Cir. 1989) ("Th[e] determination of reasonableness is made on a case by case basis by balancing the purpose of the statute and the need to protect individuals asserting their rights thereunder against an employer's legitimate demands for loyalty, cooperation and a generally productive work environment.").

39. See, e.g., Crown Zellerbach, 720 F.2d at 1014.

40. See Rollins, 868 F.2d at 401 ("If, under this balancing test, the manner in which the employee complains is found to be unreasonable, it falls outside the protection of the statute; the employee's conduct then may be deemed an independent, legitimate basis for the [alleged adverse action]."); see also Rosser, 616 F.2d at 223. In these types of cases, therefore, the employer will generally assert the defense of a nonpretextual basis for the alleged retaliatory behavior in addition to claiming that the plaintiff failed to establish a prima facie case because the alleged oppositional conduct falls outside the statute's protection.

41. See Green v. McDonnell Douglas Corp., 463 F.2d 337, 341 (8th Cir. 1972) ("[W]e find no suggestion that [Title VII] protection extends to activities which run afoul of the law."), vacated on other grounds, 411 U.S. 792 (1973); Rollins, 868 F.2d at 401 (holding that employee's conduct fell outside the scope of Title VII where employee's repeated false claims "antagonized her supervisors and colleagues and impaired the morale of her unit"); Hochstadt v. Worcester Found. for Experimental Biology, 545 F.2d 222, 230 (1st Cir. 1976) (holding employee's participation in political activity for women's liberation on company time unprotected under opposition clause); Armfield v. Runyon, 902 F. Supp. 823, 827 (N.D. III. 1995) (determining that a postal employee's threats of assault against a supervisor justified the employee's termination). See generally Brian J. Kreiswirth, Case Note, Justifiable Limitations on Title VII Anti-Retaliation Provisions, 107 YALE L.J. 2339, 2342 (1998).

42. See, e.g., Rodriguez v. Board of Educ., 620 F.2d 362, 364-66 (2d Cir. 1980) (recognizing school board's transfer of a teacher as adverse employment action where teacher's twenty years of experience were useless at new location with new students); Daines v. City of Mankato, 754 F. Supp. 681, 699-700 (D. Minn. 1990) (finding retaliatory action where employer implemented more burdensome selection procedure resulting in failure to promote previously eligible female plaintiff). For a general discussion of the scope of employer action 
a tangential effect on a victim's employment, such as changes in responsibility which do not involve alteration in benefits, compensation or status, may be evidence of retaliatory behavior. ${ }^{43}$ Once a claim of retaliation is successfully established, the employee is entitled to the full panoply of remedies available under Title VII. ${ }^{44}$

In this way, the retaliation provision of Title VII effectively insulates a broadly described group of employees from significant alteration in the terms and conditions of their employment. Once an employee legitimately invokes the statute, the retaliation provision alters the reciprocal nature of the relationship, eliminating the employer's ability to terminate the relationship at will and granting the employee a specialized form of job security. Such a result ensures that the fear or threat of financial harm and professional discredit do not deter employees in their pursuit of equal treatment and that employers do not avoid compliance by such means. The statute preserves the employment relationship in the face of conflict and locates the power to alter that relationship primarily in the employee, who is now able to engage freely in the conduct that will ideally remedy the problem of discrimination.

\section{B. The Rules: Attorney Ethics and the Duties of Confidentiality and Loyalty}

While Title VII grants employees, including in-house attorneys, ${ }^{45}$ the power to oppose and redress acts of discrimination, in-house attorneys are also subject to the

that may constitute retaliation, see generally LINDEMANN \& GROSSMAN, supra note 26 , at 66878; Essary \& Friedman, supra note 33, at 132-42; Ray, supra note 33, at 414-20.

43. See Collins v. Illinois, 830 F.2d 692, 702-04 (7th Cir. 1987) (determining that employer's lateral transfer of employee that involved loss of privileges but did not result in reduced pay or benefits could be retaliatory conduct); Trout v. Hidalgo, 517 F. Supp. 873, 890 n.67 (D.D.C. 1981) (finding adverse action including "removal of [plaintiff's] office to an undesirable location; failure to provide [plaintiff] with appropriate training; and failure to classify [plaintiff's] position at a grade comparable to that of other security specialists in the Navy with similar functions"). A growing number of courts have held, however, that to be cognizable as retaliation, the alleged adverse behavior must comprise an "ultimate employment decision." See, e.g., Mattern v. Eastman Kodak Co., 104 F.3d 702, 707 (5th Cir. 1997); Manning v. Metropolitan Life Ins. Co., 127 F.3d 686, 692 (8th Cir. 1997). Thus, complaints involving negative comments by superiors, interim performance evaluations, teasing, or general hostility from co-workers or superiors have been held not to constitute retaliation. See, e.g., Mattern, 127 F.3d at 707 ("Hostility from fellow employees, having tools stolen, and resulting anxiety, without more, do not constitute ultimate employment decisions, and therefore are not the required adverse employment actions."); Drake v. Minnessota Mining \& Mfg. Co., 134 F.3d 878, 884 (7th Cir. 1998) (finding no adverse action in "shunning" of employee by co-workers); Martin v. Kroger Co., 65 F. Supp. 2d 516, 557 (S.D. Tex. 1999) (" $[N]$ egative performance evaluations and placement on probation, even if undeserved, are not adverse employment actions giving rise to an actionable retaliation claim.").

44. In addition to back pay, reinstatement, and other equitable relief, successful claimants may now receive limited punitive and compensatory damages under the 1991 Civil Rights Act amendments. See 42 U.S.C. $\$ 1981$ a (1994). For a general discussion of the remedies available under Title VII, see generally 2LINDEMANN \& GROSSMAN, supra note 26, at 1741-1914; Ray, supra note 33 , at $429-32$.

45. See infra note 76. 
ethical rules that govern all lawyers. ${ }^{46}$ These rules are generally found in the stateadopted version of the Model Rules of Professional Conduct and have their roots in the common law of agency and fiduciary duties. ${ }^{47}$ Two primary codified obligations of the attorney, the duties of loyalty and confidentiality, have particular relevance to the problem of discrimination against employed counsel. These obligations are imposed primarily to preserve the trust and confidence considered essential to the attorney-client relationship and are broadly construed to benefit the client. ${ }^{48}$ Thus, unlike Title VII which alters the balance of power in the employment relationship in favor of the employee-attorney, the rules of professional responsibility by and large place the client's interests above those of its attorney. Therefore, the rights available to in-house counsel and the rules that govern them are squarely at odds with one another with respect to the employee-attorney's ability to oppose discrimination by her employer-client.

\section{Duty of Loyalty}

An attorney owes a duty of loyalty to her client under which she must avoid conflicts of interest. As codified under the Model Rules, ${ }^{49}$ an attorney is prohibited from pursuing representation and other interests that may be adverse to an existing client. ${ }^{50}$ Rule $1.7($ a) prohibits an attorney from representing a client "if the representation of that client will be directly adverse to another client" unless the attorney reasonably believes the representation will not be so affected and both clients

46. As previously noted, the Model Rules do not expressly contemplate their applicability to in-house attorneys. However, courts and commentators alike have generally treated the rules as equally applicable to all members of the bar, including those attorneys employed by their clients. See In re Capps, 297 S.E.2d 249, 250 (Ga. 1982); Brian D. Forrow, The Corporate Law Department Lawyer: Counsel to the Entity, 34 Bus. LAw. 1797, 1798-1804 (1979); Grace M. Giesel, The Ethics or Employment Dilemma of In-House Counsel, 5 GEO. J. LEGAL ETHICS 535, 535-36 (1992).

47. See, e.g., Maritrans GP Inc. v. Pepper, Hamilton \& Scheetz, 602 A.2d 1277, 1282-86 (Pa. 1992) (citing common law fiduciary duties as the basis for preventing attorneys from representing a former client's business competitor). See generally CHARLES W. WOLFRAM, MODERN LEGAL ETHICS $\$ 4.1$ (1986); L. Ray Patterson, Legal Ethics and the Lawyer's Duty of Loyalty, 29 EMORY L.J. 909 (1980). The rules themselves are in large part the codification of substantial state case law concerning the attorney-client relationship that predates both the Model Rules and its forerunner, the MODEL CODE OF PROFESSIONAL RESPONSIBILITY (1969) [MODEL CODE]. See 1 HAZARD, JR. \& HODES, supra note $22, \$ 206$.

48. See generally WOLFRAM, supra note $47, \S 4.1$ (discussing the need for a client to have trust and confidence in the attorney-client relationship).

49. This Article's treatment of the applicable ethical precepts focuses on the Model Rules and relevant common law as an example of the majority approach to state ethical regulation. It should also be noted that at least one court has suggested that the Model Rules and Model Code are themselves controlling in federal court, which is where Title VII suits will invariably be brought. See In re Dresser Indus., Inc., 972 F.2d 540, 543-45 (5th Cir. 1992) (refusing to rely solely on Texas disciplinary rules and concluding that "national standards of attorney conduct" apply in reviewing disqualification motion related to antitrust litigation).

50. See MODEL RULES, supra note 10, Rule 1.7. 
consent. ${ }^{51}$ The concept of adverse representation, as derived from the common law, is extremely broad. In addition to the representation of opposing interests in the same matter, ${ }^{52}$ which is nearly always prohibited, ${ }^{53}$ adverse representation includes the simultaneous representation of clients adverse to each other in different matters, whether or not the matters are related..$^{54}$

Further, under Rule 1.7(b), an attorney may not represent a client if the representation "may be materially limited by the lawyer's responsibilities to another client or to a third person, or by the lawyer's own interests." Gs Generally, this rule prohibits an attorney from taking on any representation that may ultimately impair her ability to perform zealously on behalf of an existing client in the absence of consent from both clients. ${ }^{56}$ It also broadly prohibits conflicts arising from the personal interests of the lawyer. These conflicts typically involve the personal business or financial interests of the attorney ${ }^{57}$ and may also involve situations where

51. Id. Rule 1.7(a).

52. See In Re Blatt, 201 A.2d 715, 716 (N.J. 1964) (finding attorney's conduct unethical when he switched representation from plaintiff to defendant in the same matter); $c f$. Hull v. Celanese Corp., 513 F.2d 568 (2d Cir. 1975) (disqualifying a law firm prosecuting civil rights claim against corporate defendant from representing defendant's in-house counsel who had previously worked on defense of same claim and sought to intervene in action as a plaintiff). There are relatively few cases holding expressly that it is unethical to represent opposing parties in the same matter; the dearth is most likely due to the obviousness of the proposition. See Santa Clara County Council Attorneys Ass'n v. Woodside, 869 P.2d 1142, 1155 (Cal. 1994).

53. Conflicts involving directly adverse interests in the same matter are generally considered unwaivable, whereas conflicts involving opposing interests in different matters, particularly where the matters are unrelated, might be avoided by obtaining proper consent from both clients. See generally WOLFRAM, supra note $47, \S 2.2$. Cf. MODEL RULES, supra note 10 , Rule $1.7 \mathrm{cmt}$. 5 ("[W] hen a disinterested lawyer would conclude that the client should not agree to the representation under the circumstances, the lawyer involved cannot properly ask for such agreement or provide representation on the basis of the client's consent.").

54. See In re Bentley, 688 P.2d 601 (Ariz. 1984) (holding that an attorney improperly initiated simultaneous but unrelated suits on behalf of two separate clients against each other); In re Hailey 473 N.E.2d 616 (Ind. 1985) (holding that it is impermissible to represent client in divorce proceeding and at same time represent estate seeking to avoid contract with divorce client for purchase of property); MODEL RULES, supra note 10, Rule 1.7(a) cmt. 7.

55. MODEL RULES, supra note 10, Rule 1.7(b) (emphasis added).

56. For instance, the rule prevents an attorney from representing multiple parties in a suit or transaction who may ultimately have diverging interests without proper consent. See, e.g., In re Thornton, 421 A.2d 1 (D.C. 1980) (suspending a lawyer for representing a driver and his passengers in a suit against the other driver in an auto collision, and for filing false documents with regard to obtaining his clients' consent for the multiple representation); North Carolina State Bar v. Whitted, 347 S.E.2d 60 (N.C. Ct. App. 1986) (holding that a lawyer can be disbarred for, among other things, failing to disclose the possible effect of his multiple representation to two wrongful death claimants who were obtaining settlement from a limited fund).

57. See, e.g., Dixon v. State Bar, 653 P.2d 321 (Cal. 1982)(deciding that a lawyer violated conflict of interest rule by purchasing real estate from a client which was adverse to another client, without the latter's consent); In re Dolan, 384 A.2d 1076 (N.J. 1978) (reprimanding a lawyer for dual representation of vendor and purchaser in real estate transaction where the 
an attorney's performance may be compromised due to nonfinancial personal interests or relationships. ${ }^{58}$ Thus, under the Model Rules and extant case law, an attorney must not only avoid situations that are clearly or potentially adverse to an existing ${ }^{59}$ client, she must forego any personal interests or obligations to non-clients that could possibly impair the quality of her representation.

Significantly, each of these broad prohibitions expressly places the power in the hands of the client to determine whether the attorney may pursue arguably adverse interests and continue the current representation. Specific and knowing consent of the client must be obtained after full disclosure, ${ }^{60}$ and where it is impossible for the attorney to make a complete disclosure, consent cannot be requested. ${ }^{61}$ Pursuing conflicting interests in the absence of consent constitutes a violation of the rules which could subject the attorney to discipline. ${ }^{62}$ Thus, it is the client, who in the case of corporate counsel is also the employer, who has the authority to determine whether and to what extent an attorney may pursue other interests, including personal interests, that might be adverse to the interests of the client.

In addition to vesting the client with this power, the Model Rules require that the attorney withdraw from representation in the event that her continued representation would cause her to violate an ethical rule. ${ }^{63}$ Therefore, if the attorney-employee perceives that pursuit of personal interests unsanctioned by the client-employer will

purchaser was funded by federally guaranteed financing and the lawyer failed to properly disclose his interest in the real estate). In addition, the Model Rules separately prohibit an attorney from engaging in a business transaction with a client or acquiring a business interest adverse to a client without proper consent. See MODEL RULES, supra note 10, Rule 1.8(a).

58. See In re Swihart, 517 N.E.2d 792 (Ind. 1988) (holding that a lawyer improperly represented a pregnant woman in placing her expected child with adoptive parents after the lawyer and his wife became interested in adopting the child themselves).

59. It should be noted that attorneys must also avoid, in some instances, representation adverse to a former client. See MODEL RULES, supra note 10, Rule 1.9. Because this Article focuses specifically on the problem of an in-house attorney's ethical obligations while employed, the law concerning successive representation is not discussed here. For information on successive conflicts, see generally WOLFRAM, supra note $47, \S 7.4$.

60. See, e.g., In re Lanza, 322 A.2d 445 (N.J. 1974) (deciding that lawyer improperly represented both vendor and purchaser without fully advising them of facts and areas of potential conflict or obtaining clients' consent); In re Galton, 615 P.2d 317 (Or. 1980) (holding that a lawyer improperly advised a client to invest with another client without disclosing his attorney-client relationship with the investee).

61. Such a situation might arise where duties of confidentiality to an existing client prohibit the attorney from revealing information necessary for the other client to understand the potential conflict. See MODEL RULES, supra note 10, Rule $1.7 \mathrm{cmt}$. 5 .

62. See id. Rule 1.7(a)(2). There is wide national disparity among the standards for disciplinary sanctions. However, in most states today, unified statewide disciplinary systems are in effect. See generally WoLFRAM, supra note $47, \S \S 3.1-.6$. The Model Rules state only that "whether or not discipline should be imposed for a violation, and the severity of a sanction, depend on all the circumstances." MODEL RULES, supra note 10, Scope. Most states have adopted some variation of American Bar Association recommendations put forth by the ABA in 1979,1985 , and 1989 with regard to organizational structure and procedural systems. See HAZARD, JR. \& HoDES, supra note 22, § 206 (introduction).

63. See MODEL RULES, supra note 10 , Rule $1.16 \mathrm{cmt} 2$. 
cause her to run afoul of Rule 1.7(b), she must either forego those interests or resign from her position. At the same time, the client-employer remains free, according to the rules, to discharge the attorney for the perceived disloyalty, or for other reasons, or for no reason at all. ${ }^{64}$ On the other hand, where an intended withdrawal is elective rather than compelled by the danger of an ethical violation, the attorney may not withdraw if the withdrawal will adversely affect the interests of the client. ${ }^{65}$ Thus, the attorney-client relationship is an "at will" arrangement from the perspective of the client. The attorney's ability to pursue or terminate representation is constrained by her client's interests; however, the client may hire or fire her at any time.

\section{Duty of Confidentiality}

In addition to the duty of loyalty embodied in Rule 1.7, an attorney is constrained by a strict duty of confidentiality both during the existence of the attorney-client relationship and after its termination. As codified in Rule 1.6, an attorney may not reveal "information relating to representation of a client" unless the client consents after consultation or disclosure is impliedly authorized for purposes of carrying out the representation. ${ }^{66}$ Confidential information is, thus, broadly identified as anything related to the representation, whether or not communicated to the attorney by the client in confidence. ${ }^{67}$ If the information pertains to the client and any matter in which the attorney is involved, it is arguably confidential..$^{68}$

Only two narrow exceptions to this general maxim are contemplated by Rule 1.6. ${ }^{69}$ Disclosure in the absence of consent may be undertaken for purposes of preventing the client from committing a criminal act likely to result in imminent death or substantial bodily harm. ${ }^{70}$ Disclosure is permitted but not required in such a situation and is sharply limited to prevention of future crimes of significant magnitude. ${ }^{71}$ The

64. See id. Rule 1.16(a)(3).

65. See id. Rule 1.16(b).

66. Id. Rule 1.6(a).

67. See id. Rule $1.6 \mathrm{cmt} 5$.

68. In this respect, the duty of confidentiality is much broader than the evidentiary attorney-client privilege. The principle of confidentiality binds the lawyer at all times with respect to any information related to the representation of a client. The attorney-client privilege is an evidentiary privilege that prevents an attorney from being compelled to testify regarding communications with her client involving the provision of legal advice. For a general discussion explaining the distinction between the duty of confidentiality and the attorney-client privilege, see generally $X$ Corp. v. Doe, 805 F. Supp. 1298, 1304-10 (E.D. Va. 1992); 1 HAZARD, JR. \& HODES, supra note 22, at 134-37, 142.9-10.

69. See MODEL RULES, supra note 10, Rule 1.6(b). The Model Rules elsewhere provide that an attorney must also reveal confidential information where necessary to comply with her duties of candor toward the tribunal, see id. Rule 3.3(b), and suggest that an attorney may reveal limited information to the tribunal. Those rules, however, are not implicated by the inhouse counsel discrimination problem.

70. See id. Rule 1.6(b)(1).

71. A number of states, however, have adopted versions of the rule that permit disclosure of any future crime or future fraud. See, e.g., PENNSYlvania Rules of PROFEssional CONDUCT Rule 1.6(c)(1)(1996) ("A lawyer may reveal such information to the extent that the lawyer reasonably believes necessary ... to prevent the client from committing a criminal act 
other exception involves disputes between the attorney and client. Rule 1.6(b)(2) permits a lawyer to disclose confidential information "to establish a claim or defense on behalf of the lawyer in a controversy between the lawyer and the client," to respond to criminal or civil claims involving the lawyer's conduct, or to respond to allegations in a proceeding concerning the representation of a client. As derived from the common law, this exception generally contemplates situations such as a client's suit against its attorney for malpractice, charges against the attorney in connection with wrongdoing of the client, or proceedings by an attorney to recover unpaid fees. ${ }^{72}$ In those situations, the use of confidential information by the attorney in pursuit of her claim or defense necessarily occurs after the termination of the attorney-client relationship.

As in the context of attorney loyalty, the client has a tight hold on the reins that restrict the attorney's ability to engage in behavior unfavorable to the client where confidential information is at issue. Where confidential information does not fall into the narrow exceptions contemplated by Rule 1.6(b)(1), but maintaining silence would otherwise compromise an attorney's ability to ethically represent her client, the attorney's only remedy is to withdraw. ${ }^{73}$ In such a situation, the duty of confidentiality will survive the duration of the attorney-client relationship. ${ }^{74}$ Moreover, where disclosure is permitted under a recognized exception, the attorney is still obligated to limit the disclosure to the necessary persons or tribunal and avail herself of appropriate protective orders to limit the potential harm to the client. ${ }^{75}$ Termination of the attorney-client relationship remains the prerogative of the client whenever a dispute arises with respect to revelation of confidential information.

Given this structure, the rules of ethics create a very different balance of power between the attorney and client than that enabled between the employer and employee under Title VII. The conflict of interest rules seemingly demand absolute attorney loyalty, which can be enforced at the will of the client. Whereas Title VII, through its anti-retaliation provision, sanctions a species of "disloyal" behavior, that is, oppositional conduct intended to eradicate perceived discrimination, the Model Rules would prohibit an attorney-employee from pursuing any outside or personal

that the lawyer believes is likely to result in death or substantial bodily harm or substantial injury to the financial interests or property of another."). Some also permit disclosure to rectify past fraud that the lawyer had unknowingly facilitated. See id. Rule 1.6(c)(2).

72. See, e.g., Cannon v. U.S. Acoustics Corp., 532 F.2d 1118, 1120 (7th Cir. 1976) (permitting lawyer to proceed to trial and reveal client confidences necessary to collect his fee for legal services rendered); In re Robeson, 652 P.2d 336, 344 (Or. 1982) (deciding that attorney was free to testify as to attorney-client communications to the extent that they were relevant to his defense against charges of unethical conduct); MODEL RULES, supra note 10, Rule $1.6 \mathrm{cmt}$. 18 (explaining confidentiality exception enabling attorney to respond to claims or disciplinary charges alleging attorney complicity in client conduct or other attorney misconduct involving the representation of a client).

73. See MODEL RULES, supra note 10, Rule 1.16(b)(1)-(3); cf. id. Rule 1.13(c) (providing that withdrawal, as opposed to disclosure, is the proper course of action where an organizational client insists upon acting in a manner that violates the law and is likely to result in substantial injury to the organization despite the lawyer's remonstrations).

74. See id. Rule 1.6.

75. See id. Rule $1.6 \mathrm{cmt} .18$. 
interests either directly or potentially adverse to her client-employer. Moreover, while Title VII seeks to preserve the status quo employment relationship, the Model Rules establish a default withdrawal regime. Where conflict arises between employer and employee over alleged discriminatory behavior, the statute prohibits the employer from terminating or adversely altering the employment status of the objecting party on the basis of the protected conduct. Where conflict arises between attorney and client, the client has the absolute right to terminate the relationship.

\section{QUESTIONS PRESENTED AND QUESTIONS DEFLECTED}

Given the existence of these parallel yet potentially conflicting doctrines, what rights and obligations govern an in-house attorney subject to workplace discrimination? The question begs both a pragmatic and academic consideration of the governing laws and their purposes. On a practical level, it is unclear whether an in-house attorney may oppose discrimination while employed and what information she can use in pursuing that claim. This leaves the in-house attorney with little incentive to oppose discrimination in the workplace, for in doing so she risks the nonredressable termination of her employment and has no guarantee that she will be able to pursue her claim to its fullest. From a broader perspective, the conflict implicates the profession's concept of loyalty: how it relates to the attorney-client and employer-employee relationships, its breadth, characteristics, and justifiable limitations.

The following Part explores courts' responses to cases involving in-house attorneys who engage in what would otherwise be considered protected conduct under Title VII. As demonstrated below, the existing case law betrays two different and largely inconsistent analytical approaches: courts either avoid the ethical rules or use the rules to prohibit the exercise of Title VII rights. The few decisions dealing with attorneys who bring Title VII claims while employed have generally fashioned factspecific results that ignore the Model Rules and the ethical dimension of the problem. ${ }^{76}$ At the same time, a recent case involving an attorney who engaged in internal protests of discriminatory behavior has held that conduct by attorneys in

76. See, e.g., Jones v. Flagship Int'l, 793 F.2d 714 (5th Cir. 1986); Terry v. Gallegos, 926 F. Supp. 679 (W.D. Tenn. 1996); Verney v. Pennsylvania Turnpike Comm'n, 903 F. Supp. 826 (M.D. Pa. 1995); see also infra Part II.A. While discrimination and harassment claims by attorneys are far from rare, most reported cases involving such claims arise after the individual attorney is terminated. See, e.g., Kier v. Commercial Union Ins. Cos., 808 F.2d 1254 (7th Cir. 1987); Kocher v. Acer Inc., No. C-93-20132 RMW (PVT), 1993 WL 149077 (N.D. Cal. May 7, 1993); Rand v. CF Indus., Inc., 797 F. Supp. 643 (N.D. Ill. 1992). In those situations, while an attorney retains obligations of confidentiality toward her former client-employer, her duties of loyalty are fundamentally different. Compare MODEL RULES, supra note 10, Rule 1.7, with id. Rule 1.9. 
opposition to workplace discrimination and in violation of the ethical rules is never protected under Title VII. ${ }^{77}$ Thus, the existing cases fail to provide a uniform approach or a satisfactory analysis of the conflict. ${ }^{78}$

\section{A. Rules Avoided: Analysis of Attorney Claims Through the Title VII Burden of Proof Structure}

Those Title VII decisions dealing with in-house attorneys who initiate legal action while employed have focused on the legitimacy of the employer's proffered reasons for its behavior as in the context of a typical workplace discrimination dispute. In Jones, for instance, a licensed attorney employed as an Equal Employment Opportunity ("EEO") manager in a private company filed a charge with the Equal Employment Opportunity Commission alleging sexual harassment and other forms of discrimination against her employer-client. ${ }^{79}$ Upon learning of the charge, the company immediately suspended her, citing "conflict of interest" concerns ${ }^{80}$ Shortly thereafter, the employer-client discovered that the plaintiff had invited other female employees to join her in a threatened class action suit, and terminated her. ${ }^{81}$ The plaintiff brought suit, claiming both discrimination and retaliation. ${ }^{82}$

In analyzing the plaintiff's retaliation claim, the Fifth Circuit did not address the conflict between the Model Rules and the availability of Title VII relief to employed attorneys, but instead concluded on the merits of the case that the defendant had presented sufficient evidence to rebut the plaintiff's claim of retaliation. ${ }^{83}$ The court determined that the plaintiff was legitimately fired for her inappropriate behavior in threatening and inciting class action litigation. ${ }^{84}$ It explicitly declined to address whether the defendant would have been justified in firing the plaintiff based solely on her filing of the charge ${ }^{85}$ and ignored completely the question whether an in-

77. See Douglas v. DynMcDermott Petroleum Operations Co., 144 F.3d 364, 376-77 (5th Cir. 1998); see also infra Part II.B.

78. The use of the word conflict here refers to the general problem of resolving the competing interests at stake between the two bodies of law implicated by the in-house counsel discrimination problem. It is unclear whether an actual conflict of law exists that would require consideration of principles of federal preemption. Preemption has been alluded to by courts asserting the general proposition that attorneys are not exempt from the federal civil rights laws. See, e.g., Stinneford v. Spiegel Inc., 845 F. Supp. 1243, 1246 (N.D. Ill. 1994) (noting that "the Supremacy clause demands that the federally mandated protection of the [Age Discrimination in Employment Act] triumph over the state principle of at-will employment" in concluding that terminated in-house attorney could pursue age discrimination claim against former employer); Rand, $797 \mathrm{~F}$. Supp. at 647 . However, no court dealing with the limits of protection afforded to employed in-house attorneys has invoked these concerns. An analysis of the problem from the perspective of constitutional federalism is therefore beyond the scope of this Article.

79. Jones, 793 F.2d at 716 .

80. Id. at 717 .

81. See id.

82. See id. at 718.

83. See id. at 730.

84. See id. at 725-29.

85. See id. at 726 ("We need not address ourselves ... to whether Flagship's response, if 
house attorney who initiates suit against her current employer places herself outside the protection of Title VII.

To the extent the court treated the specifics of the conflict of interest offered in justification of the company's behavior, it did so in light of the plaintiff's position as an EEO manager as opposed to her duties as an attorney. ${ }^{86}$ In response to the argument that the plaintiff's solicitation of employees was itself protected conduct, the court invoked the balancing test utilized to determine whether the manner in which an employee protests discrimination is unreasonable ${ }^{87}$ and concluded that in the case at hand the attorney's conduct fell outside the scope of the statute. ${ }^{88}$ In so doing, the court alluded to the plaintiff's familiarity with other discrimination claims against the employer and her own representation of the company in those proceedings. ${ }^{89}$ However, it treated these factors not as violations of an attorney's professional obligations but as undermining the "great confidence" which employers repose in their "EEO personnel." "In a leap unsupported by any factual information contained in the decision, the court concluded that the plaintiff"s conduct "critically harmed [the employer]'s posture in the defense of discrimination suits brought against the company" and rendered the plaintiff "ineffective [for] the position for which she was employed."191 In this way, the court deflected the critical question whether an in-house attorney may be terminated for engaging in protected conduct, purporting instead to treat the issue as one involving a fact-specific determination about the scope of protection afforded to an employee charged with EEO responsibilities.

A somewhat similar approach, yielding a different outcome, was taken by the district court in Verney. ${ }^{92}$ There, an in-house attorney filed a charge for discriminatory failure to promote, and was terminated two years later while her case was pending in court. ${ }^{93}$ She subsequently filed a retaliation complaint against her employer-client and

based on Jones' filing of the charges alone, was sufficiently excessive to constitute unlawful retaliation.") (emphasis in the original).

86. The court's failure to explicitly treat Jones as an attorney and evaluate her attendant ethical obligations seems almost disingenuous in light of the factual evidence presented in the case, including the employer's discharge letter to Jones and the employer's oral testimony at trial, which indicate that the company's concerns stemmed from the perceived conflict between the plaintiff's obligations as its attorney and her pursuit and encouragement of adverse litigation. References to such evidence, however, are found only in the footnotes to the court's opinion. See id. at 717 n.3, 726 n.14.

87. See supra Part I.A.

88. See Jones, 793 F.2d at 728 (observing that "“[t]here may arise instances where the employee's conduct in protest of an unlawful employment practice so interferes with the performance of his job that it renders him ineffective in the position for which he was employed. In such a case, his conduct, or form of opposition, is not covered by [the retaliation provision]'") (alterations added) (quoting Rosserv. Laborers' Int'I Union of N.Am., Local No. 438,616 F.2d 221, 223 (5th Cir. 1980)).

89. See Jones, 793 F.2d at 728.

90. Id.

91. Id.

92. Verney v. Pennsylvania Turnpike Comm'n, 903 F. Supp. 826, 826 (M.D. Pa. 1995).

93. See id. at 828. 
several individual employees. ${ }^{94}$ During discovery, one of the defendants admitted that the plaintiff's lawsuit was one of the factors leading to the employer's decision to terminate her..$^{95}$

In its motion for summary judgment, the defendant did not deny that the plaintiff's suit played a part in its decision, but asserted that the plaintiff's discharge was due to a number of factors, including

an erosion of trust and confidence in her ability to serve as an attorney, evidenced by her (1) surreptitious documentation of conversations with ... employees ...; (2) her inability to deal with outside counsel; (3) withdrawal from other members of the legal department ...; and (4) actions that reflected poor judgment [and] unwillingness to take direction or criticism. ${ }^{96}$

The court agreed that these reasons would constitute legitimate bases for termination if true, ${ }^{97}$ but failed to discuss the ethical rules or the fact that the reasons asserted by the defendants directly implicated the trust and loyalty which the rules and common law so vehemently safeguard. The court reasonably declined to read Jones as permitting termination based solely on the filing of a claim $^{98}$ and, applying Title VII's shifting burdens of proof, denied the defendants' motions for summary judgment on grounds that issues of fact existed as to whether the reasons offered for the termination were legitimate or pretextual. ${ }^{99}$ In this way, the Verney court resolved the particular matter before it by forcing the parties to a factual showdown regarding the presence or absence of pretext rather than providing guidance on the threshold issues regarding the applicability of statutory protection.

Thus both Jones and Verney involve fact patterns that clearly implicate the conflicting duties owed between attorney and client in the context of in-house counsel claims, yet in each case the court deflects the overriding issue of attorney ethics. Instead these cases rely on Title VII's burden of proof structure to resolve what could be characterized as a generic workplace conflict. The courts focus their analysis on the presence or absence of pretext under the instant facts, thus passing over the initial question whether an attorney who files a claim can establish a prima facie case of retaliation in light of the conflicting provisions of the Model Rules. Resolution of these cases therefore turns on an evaluation of the facts supporting termination, as in any other case involving an employee suing her employer, rather than on the availability of a defense based on the attorney's violation of her ethical obligations.

\section{See id.}

95. See id. at 831.

96. Id.

97. See id.

98. In so doing, the court rejected the defendants' assertion that permitting termination based solely on the filing of the claim might be appropriate in the "unique" facts before it. Id. at 832. Although the court does not explain its meaning, it bears noting that the word "unique" has become almost a term of art in characterizing the attorney-client relationship and is invariably invoked in justifying the special obligations with which attorneys have traditionally been saddled. See, e.g., Herbster v. North Am. Co. for Life \& Health Ins., 501 N.E.2d 343, 346 (IIl. App. Ct. 1986) (citing attorney's unique position in society and special relationship with client in support of decision to deny in-house counsel's wrongful discharge claim).

99. See Verney, 903 F. Supp. at 833. 


\section{B. Rules Exalted: Ethical Rule Violation As a Bar to Statutory Protection}

The analysis in Jones and Verney stands in sharp contrast to the treatment of protected conduct exhibited in a recent post-termination decision by the Fifth Circuit, the same court that heard Jones. In Douglas v. DynMcDermott Petroleum Operations $C o$, the court broadly announced that conduct violative of the professional duties of loyalty:and confidentiality is not protected by Title VII in the context of a retaliation suit by an in-house attorney. ${ }^{100}$ There the plaintiff-attorney was employed by a private company that oversaw the Department of Energy's ("DOE") petroleum reserve facilities. ${ }^{101}$ At a meeting with DOE auditors, the plaintiff was asked whether she was aware of any equal pay claims by female employees. ${ }^{102}$ She responded that she was not, but that "maybe [she would] get [her] money now," and offered her opinion that the employment law compliance situation at her company was a "class action waiting to happen." ${ }^{103}$ Following the meeting, the plaintiff received a written performance evaluation in which she was criticized for exercising poor judgment during the auditors meeting. ${ }^{104}$ The plaintiff forwarded a written response to the general counsel, a DOE whistle blower officer, and several other employees. ${ }^{105}$ In the letter, she complained that she had been subjected to race and sex discrimination and discussed the discrimination complaint of another employee and a transaction the plaintiff had handled for the company. ${ }^{106}$ When the employer learned about the response, it terminated her. ${ }^{107}$

Reviewing the plaintiff's subsequent retaliation claim, the Fifth Circuit held that the plaintiff's conduct constituted a breach of her duties of confidentiality and loyalty and was consequently unprotected as a matter of law. ${ }^{103}$ Analyzing the conduct first under the applicable state professional rules, the court determined that the information contained in the response letter concerning the employee and the transaction constituted confidential information gained during the representation not subject to any of the exceptions that permit disclosure. ${ }^{109}$ In so concluding, the court summarily dismissed the plaintiff's argument that the disclosure fit within the exception for establishing a claim in a dispute between the lawyer and the client. ${ }^{110}$ Turning to the

100. 144 F.3d 364, 376-77 (5th Cir. 1998).

101. See id. at 366.

102. See id.

103. Id. at 366-67.

104. See id. at 367.

105. See id.

106. See id.

107. See id.

108. See id. at 369 .

109. See id. at 369-72.

110. The court's disregard of that exception was based not on an analysis of the applicability of the exception to discrimination claims, but on its determination that the subject matter of the response letter did not constitute a controversy between the plaintiff and the client. See id. at 372. This conclusion was itself based on the largely irrelevant fact that, in response to a phone call from the DOE whistle blower officer, the plaintiff told the officer that her response letter was not a whistle blower complaint. See id. 
federal statute, the court properly addressed itself to the initial question whether the plaintiff's conduct was protected in light of her professional obligations. However, it sought to resolve that issue through an unusual and seeming misapplication of the test designed to exclude excessively disruptive and unreasonable conduct from statutory protection. The court did not balance the manner in which the plaintiff registered her protest and the tangible effects of the conduct, or in this case the alleged rule violation, on the employer's ability to conduct its business. Though it recited the principle that courts must look to the effect of the oppositional conduct on the plaintiff's ability to perform, ${ }^{11 \prime}$ the court did not consider any factual evidence relating the plaintiff's job performance or the employer's belief that she was ineffective in her position. Rather, it weighed and compared two abstract principles: the expectation of the employer that in-house counsel will abide by the rules of professional ethics, and the attorney's right to oppose allegedly discriminatory practices. ${ }^{112}$ Citing the in-house attorney's "unique position of special trust" and the client's "concomitant position of vulnerability," as well as the interests of the legal profession in maintaining the integrity and reputation of its officers, the court concluded that the interests of employers and the profession must prevail over attorneys' individual rights. ${ }^{113}$ Thus, the court broadly announced that conduct that breaches the ethical duties of the legal profession is unprotected as a matter of law and that an attorney who violates those duties is not entitled to any damages flowing from retaliation taken by her employer-client. ${ }^{114}$

Unlike the holdings of Jones and Verney, the Douglas decision uses the ethical rules as the touchstone for analyzing attorney claims and makes rule compliance the prerequisite to statutory protection. While Douglas involves a post-termination lawsuit, and more closely implicates the duty of confidentiality than the duty of loyalty, its method of analysis would apply equally to the problem posed by a pretermination lawsuit as in Jones and Verney. It is clear that Douglas's conduct was in protest of what she perceived as discriminatory treatment directed both toward herself and to other employees. Although the court pays lip service to the idea that Douglas's conduct rendered her ineffective in her position, like Jones, it provides no factual support for that contention. It focuses throughout the opinion on ethical principles, not job performance. The court compares the rights of an employee and the obligations of an attorney and, in dualistic terms, concludes that the latter trumps the former. Individual rights and the plaintiff's expectations as an employee are sacrificed

111. See id. at 374-75.

112. See id. at 375-76.

113. Id. at 375 .

114. See id. at 376-77; see also Sokolow v. City of League City, 37 F. Supp. 2d 940, 945 (S.D. Tex. 1999) (declining to determine whether city attorney's conduct in drafting memo condemning racially offensive comments was protected conduct but noting that "a real or perceived violation of an ethical duty, even when that violation pertains to Title VII, can. provide a legitimate basis for termination" in granting summary judgment to defendant-client); cf. Hull v. Celanese Corp., 375 F. Supp. 922, 924 (S.D.N.Y. 1974) (denying motion by corporate attorney to intervene as plaintiff in discrimination suit brought against her employer where attorney's prior work on defense of same matter created risk of disclosure of confidential information in violation of ethical canons). 
explicitly ${ }^{115}$ to the ideals of the legal profession and what the court perceives as the needs of the client within the context of an attomey-client relationship.

\section{FROM A ClASH OF IDEALS TOWARD CONCOMITANT OBLIGATIONS}

The failure of the existing case law to yield any common framework for resolving these issues, and the courts' reluctance to confront the implicit problem, betrays deeper tensions in the status and perception of in-house counsel and attorneys generally. Whereas the problem of discrimination against in-house counsel may be viewed from the perspective of two discrete areas of substantive law, neither can adequately account for the legitimate competing interests at stake in such a conflict. Indeed, the difficulty of crafting this problem as an issue pertaining to either legal regime is itself revealing insofar as it points to a fundamental shortcoming in our conception of professional ethics: The duties of an attorney are imposed and interpreted wholly apart from any acknowledgment of individual rights in the context of the attorney-client relationship. The following subpart takes issue with the dualistic approach to the attorney-employee distinction exhibited in the current case law and criticizes the current construction of attorney ethics that entirely disregards lawyers' legitimate self-interests. The subpart then offers several justifications for affording in-house attorneys the ethical latitude to redress workplace discrimination without fear of reprisal, taking into consideration the theoretical underpinnings of the concept of absolute loyalty and the realistic circumstances under which corporate attorneys practice.

\section{A. A Conflict of Absolutes}

The existing case law involving attorneys engaged in otherwise protected conduct suggests that the possible means of addressing in-house counsel rights in this context are two fold and mutually exclusive: Under one approach, corporate counsel is treated purely as an attorney, so that the ethical rules become the benchmark for what may be considered the proper exercise of rights under Title VII. Under the other, professional ethics are wholly ignored, leaving the attorney to be treated as any employee. These approaches reflect two distinct and equally understandable absolutes.

On one level, the problem posed by the in-house counsel situation, and by consequence its resolution, is simple. ${ }^{116}$ Removing the cloak of federal rights and

115. See Douglas, 144 F.3d at 376 (asserting that the interests of the profession and the client "must prevail" over the attorney's individual rights).

116. What appears to be a simple question of applicable law in the ethics arena often masks more complicated issues involving the limits of lawyers' professional obligations. Scholarship has criticized the approach to legal ethics that seeks easy answers to questions of this nature. See, e.g., Eleanor W. Myers, "Simple Truths" About Moral Education, 45 AM. U.L. REV. 823, $848 \&$ n.124 (1996) (noting that the ordinariness and recurrence of ethical questions belies their complexity); Patterson, supra note 47, at 957 (critiquing the quasi-legal status of ethical rules as permitting a one-dimensional approach to ethical issues that responds to questions in "black or white terms"); William H. Simon, "Thinking Like a Lawyer" About Ethical 
viewing the situation purely from the perspective of legal ethics, the question raised is whether an attorney can sue her own client while maintaining the pre-existing attorney-client relationship. The answer, obvious from the legacy of both the common law and attempts to codify ethical precepts, is a resounding "no." 117 Any other response not only sanctions attorney conduct that runs against all inherent assumptions about professional loyalty, but, in the context of this particular scenario, would arguably compel a client to retain an attorney in whom the client had lost trust. ${ }^{18}$ Thus, to the extent the question has been considered, it has generally been assumed that an attorney subject to discrimination would be obligated to resign if she wished to pursue a claim. ${ }^{119}$

Given the inevitable result under the ethics rules, it is not surprising that courts might prefer to analyze the problem solely from the perspective of the Title VII doctrine, for they would otherwise be hamstrung to an approach that denies attorneyemployees basic statutory protections. While the rule-exalting approach utilized in Douglas has the value of ensuring a uniform level of objective ethical compliance consistent with generally accepted practices, it effectively exempts in-house counsel positions from the job protection aspects of Title VII. ${ }^{120}$ The implication of such a result would be to force employed attorneys subject to discrimination or harassment either to suffer in silence or quit to pursue their federal rights, an effect that from the perspective of employment law stands the purpose of the statute on its head. Permitting employers to terminate otherwise protected employees based solely on

Questions, 27 HOFSTRA L. REV. 1, 3-4 (1998) (describing the mainstream approach to ethical decisionmaking as a matter of simplistic judgment).

117. As one court noted, the proposition is so obvious that it has scarcely been recorded in published case law. See Santa Clara County Counsel Attorneys Ass'n v. Woodside, 869 P.2d 1142, 1155 (Cal. 1994).

118. The idea that a client might be forced to continue employing an attorney against its will is particularly offensive to existing principles of legal ethics and common law regarding the attorney-client relationship. The right of the client to sever the attorney-client relationship at will is considered "bedrock law." See General Dynamics Corp. v. Superior Court, 876 P.2d 487, 493 (Cal. 1994); see also Corti v. Fleisher, 417 N.E.2d 764, 769 (Ill. App. Ct. 1981) ("[E]ach person must have the untrammeled right to the counsel of his choice."); Dwyer $v$. Jung, 336 A.2d 498, 500 (N.J. Super. Ct. 1975) ("A client is always entitled to be represented by counsel of his choosing .... No concept of the practice of law is more deeply rooted.").

119. See Kocher v. Acer Inc., No. C-93-20132 RMW (PVT), 1993 WL 149077, at *6 (N.D. Cal. May 7, 1993) (noting in review of claim by in-house attorney terminated for threatening to bring claim for discrimination that plaintiff could not have brought such a claim while continuing his employment); Moore, supra note 9, at 543; cf. Weaver, supra note 1 , at 1050 (favoring internal resolution of in-house counsel discrimination disputes over pursuit of employment litigation).

120. This Article does not suggest that the rule-exalting approach utilized in Douglas would preclude an in-house attorney from engaging in any type of protective conduct. An attorneyemployee would presumably be free to voice opposition to questionable practices within the company through appropriate corporate channels. One might argue that such conduct is sanctioned, if not required, by the ethical rules, which obligates corporate attorneys to take measures to ensure that their client upholds the law. See MODEL RULES, supra note 10, Rule 1.13 . 
their status as attorneys gives the employer a license to discriminate and does serious injustice to the rights of the individual victim.

For these reasons, the applicability of the ethical rules to an in-house attorney in conflict with her employer in this context cannot be considered apart from the individual rights of attorney-employees. Given the current understanding of the doctrine of legal ethics, the assumption that the ethical rules establish a bar to certain protected behavior presents an insurmountable hurdle to enforcing pre-termination rights. Yet an approach that considers solely Title VII fails to accommodate legitimate client concerns regarding the fidelity of counsel and potentially jeopardizes the professional status of in-house employees. ${ }^{121}$ The existing case law thus reveals a need for an approach that reaches outside the attorney-employee dichotomy and attempts a genuine and integrated consideration of the competing rights and interests that attach to what are currently seen as divisible roles.

\section{B. Role Confusion, Loss of Self, and the Complications of a Commercialized Profession}

The chief obstacle to a more considered approach to the in-house counsel discrimination problem is the accepted concept of professional loyalty that supposes total abdication by the attorney of all "adverse" interests without any consideration of the nature of the interests involved or their effect on the professional relationship. While imposing these duties on the attorney, the law of ethics fails to recognize any concomitant obligations on the part of the client or consider the extent to which the conduct of the client creates the conflict at issue. While problematic on several levels, this model of attorney-client responsibility is particularly ill-equipped to respond to discrimination against employed counsel. Given the nature of the in-house counsel relationship and the source of conflict generated by workplace discrimination, a more balanced and context-based definition of loyalty and conflict is appropriate.

\section{Deconstructing Loyalty: Images and Realities of the Attorney-Client Relationship}

The underlying image of the attorney on which modern ethical precepts are based is that of an "undivided partisan" who owes total allegiance to the client. ${ }^{122}$ The

121. A chief argument against permitting suits by in-house attorneys in other contexts, often championed by in-house attorneys themselves, has been the concern that allowing suits by inhouse counsel will result in a two-tiered profession in which in-house counsel are subject to lesser standards of professional behavior. See Board of Directors of the American Corporate Counsel Association Policy Statement on Wrongful Discharge Suits Filed by In-House Counsel (adopted Nov. 6, 1991). This Author believes that such concerns, while not unfounded, should not be viewed as an absolute obstacle to recognition of in-house counsel's employment rights, particularly in light of the increased status of in-house counsel within the profession. See Sally R. Weaver, Client Confidences in Disputes Between In-House Attorneys and Their Employer-Clients: Much Ado About Nothing-Or Something?, 30 U.C. DAVIS L. Rev. 483, 536 (finding concerns about differential treatment of in-house attorneys "overstated"); infra note 141; discussion infra Part III.B.2.

122. See Deborah L. Rhode, Ethical Perspectives on Legal Practice, 37 STAN. L. REv. 589, 
attorney is depicted as a zealous advocate engaged in an adversarial process on behalf of a vulnerable individual who has placed absolute trust and confidence in the attorney to safeguard his or her interests. The attorney must do everything within legal bounds to advance the client's ends without allowing her personal sense of justice or the interests of third parties to diminish the efficacy of her representation.

The origins of this imagery are owed largely to general concepts of professionalism and the belief that the lawyer-client relationship is unique among professional relationships. By its nature, the idea of a profession connotes service to another, and it is therefore assumed that the pursuit of a profession entails some degree of selfsacrifice on behalf of those one serves. ${ }^{123}$ With respect to the legal profession, lawyers have specialized knowledge and training to which the average client does not have access but which the client needs in order to advance or defend against a claim. Because the lawyer's services in this respect are esoteric and technical in nature, the client is presumably not able to evaluate the quality of the service provided in relation to the client's need. ${ }^{124}$ The client's ability to obtain effective representation, however, is crucial to his or her ability to exercise the rights and protections afforded by the legal system to their fullest extent and thus to gain full autonomy within society. ${ }^{125}$ For all of these reasons, the client is placed in a position of significant dependence vis-à-vis the attorney, who is the sole source of a service that is both essential and inscrutable to the person who will be affected by it.

Given this significant power imbalance, the obligation of professional loyalty serves as a safeguard that will ideally prevent abuse of power and ensure that the client's interests are advanced to their fullest. ${ }^{126}$ Under the prevailing view, the duty of loyalty requires the attorney to devote herself fully to the client on several levels: She must refuse to accept any employment that would place her in a position adverse to her client and, further, she is obligated to set aside her personal interests to the extent they might interfere with her ability to act on the client's behalf. The latter aspect of the obligation evokes the related requirement of professional neutrality. In addition to assuming an undivided commitment to advancing the client's cause or position, the attorney is expected to set aside her own view of the legitimacy of the client's aims, thus ensuring that clients will not be denied access to legal services, and consequently the ability to exercise rights, based on the predilections of attorneys. ${ }^{127}$ Together these professional obligations personalize the attorney-client relationship from the perspective of the client while depersonalizing it from the perspective of the

594 (1985).

123. See Stephen L. Pepper, The Lawyer's Amoral Ethical Role: A Defense, a Problem, and Some Possibilities, 1986 AM. B. FoUND. RES. J. 613, 615.

124. See Ronald J. Gilson, The Devolution of the Legal Profession: A Demand Side Perspective, 49 MD. L. REV. 869, 889 (1990) (identifying informational asymmetry between lawyer and client as the distinctive characteristic of the market for legal services).

125. See Pepper, supra note 123, at 616-17.

126. See id. at 616. That is not to say that technical compliance with the governing rules can in itself ensure ethical behavior, and the Model Rules themselves contemplate that lawyers will be guided by personal conscience in delivering legal services. See MODEL RULES, supra note 10, Scope ("The Rules do not ... exhaust the moral and ethical considerations that should inform a lawyer, for no worthwhile human activity can be completely defined by legal rules.").

127. See Pepper, supra note 123, at 616-17. 
attorney. By requiring the attorney to forgo conflicting professional interests, the concept of loyalty aligns the attorney's own interests with those of her client; the lawyer is not a hired gun who will advocate for whatever position she is paid to support, but is a personal agent of the client who is invested financially and emotionally in the success of representation. At the same time, by requiring the attorney to set aside personal preconceptions, the obligation of neutrality ensures that the lawyer pursues the representation with the mind-set of a detached professional; it forces the attorney to remove herself from the service she provides. ${ }^{128}$

Thus the model of the attorney-client relationship that underlies the construct of attorney loyalty is one that involves abdication of self in order to enhance client autonomy. Considered in this light, an effort by an in-house attorney not only to identify but also to redress what she considers wrongdoing on the part of the client runs entirely counter to the values underlying the legal ethics rules.

A significant problem with the existing model, however, is that in its attempt to rectify a perceived imbalance of power and ensure client access to quality representation, it fails to recognize any concomitant responsibilities on the part of the client in delineating the limits of the attorney's obligations. ${ }^{129}$ Of course, certain constraints govern the type of representation a client may obtain: An attorney is prohibited from assisting a client in the commission of a crime or fraud both by the ethical rules and applicable law, ${ }^{130}$ and an attorney is always free at the outset to refuse to accept a client for any reason. ${ }^{131}$ However, the client's only affirmative duty to the attorney during the course of representation is to fulfill the financial obligations

128. The idealization of attorney neutrality has been fodder for the increasingly vocal critique that lawyers wrongfully escape all moral responsibility for the aims and ends of those they represent. See Richard W. Painter, The Moral Interdependence of Corporate Lawyers and Their Clients, 67 S. CAL. L. REV. 507, 510 (1994) (noting that the combined principles of loyalty and neutrality permit lawyers to go to extremes on behalf of their clients and grant lawyers the authority to set the only limits on those extremes). Along with the growing public demand for greater accountability in the legal profession, scholars have called for approaches to legal ethics that allow for and encourage lawyers to think critically and independently about the work in which they engage. See id.; WILLIAM H. SIMON, THE PRACTICE OF JUSTICE 138-69 (1998) (arguing for a contextual approach to legal ethics whereby lawyers may take the actions most likely to promote justice under the particular circumstances of a given case); Myers, supra note 116 , at $855-58$.

129. See David B. Wilkins, Do Clients Have Ethical Obligations to Lawyers? Some Lessons from the Diversity Wars, 11 GEO. J. LEGAL ETHICS 855, 886 (1998) ("Rather than serving as a mechanism for protecting vulnerable clients from overreaching by their lawyers, the agency model facilitates a situation in which savvy clients make extraordinary and potentially illegitimate demands on their lawyers without ever having to justify these demands in terms of anything other than their self-interest.").

130. See MODEL RULES, supra note 10, Rule 1.2(d).

131. See id. Scope (noting that "[m]ost of the duties flowing from the client-lawyer relationship attach only after the client has requested the lawyer to render legal services and the lawyer has agreed to do so"). Of course, the attorney's prerogative not to represent a client is sharply constrained once representation has begun. See id. Rule 1.16(b) (delineating circumstances under which a lawyer is permitted to withdraw from representing a client if withdrawal can be accomplished without material adverse effect on the client's interests); supra Part I.B.1. 
of the parties' contract, namely to pay for services rendered. ${ }^{132}$ There are no reciprocal responsibilities to the fiduciary obligations assumed by the attorney, nor even any expectation or requirement that the client will act in good faith. ${ }^{133}$

This system allows the client to exact a complete investment by the attorney without incurring any responsibility for the attorney's well-being or ability to perform within the relationship. Setting aside the question whether such a model is proper under any justification, it seems particularly suspect given its theoretical underpinnings and the realities of modern legal practice. Whereas the model contemplates clients unable to access or evaluate the legal services they require, in actuality modern law firms compete vigorously to market themselves and elicit business from an increasingly discriminating base of high-powered corporate clients. ${ }^{134}$ It is now routine, for instance, for large law firms to engage in advertising schemes to solicit business, for clients to request and review proposed budgets and strategies in selecting counsel for complex work, and for law firms to reduce their normal rates or enter into a variety of concessions to appease and obtain valuable clients. ${ }^{135}$ Once counsel is retained, clients exercise a significant degree of control over the day-to-day work that lawyers do, participating in strategic decisionmaking and evaluating carefully the costs involved in what might traditionally have been considered lawyers' choices. ${ }^{136}$

132. See Restatement OF THE LAW GOVERNING LAWYERS $\$ 29$ (Tentative Draft No. 5 , 1992).

133. In comparison, agency law generally contemplates that the principal assumes a duty to act in good faith vis-à-vis the agent and not to interfere with agent's ability to serve. See Wilkins, supra note 129, at 881 (comparing obligations of client toward attomey with obligations owed by principal to agent); see also HAROLD GILL REUSCHLEIN \& WILLIAM A. GREGORY, THELAWOF AGENCY AND PARTNERSHIP $\$ \$ 83,85$ (2d ed. 1990). Indeed since these obligations are generally implied as contractual provisions within an agency relationship, it might be said that the client's duties to the attorney are less than contemplated by contract while the attorney's duties include extracontractual obligations.

134. This statement and the discussion that follows focus specifically on corporate clients, since it is these clients who will be affected by a recognition of in-house counsel's ability to exercise rights under Title VII. It should be noted that many of the changes with respect to corporate clients' ability to manage and control their relationships with counsel are the result of the developing presence of in-house legal departments whose members have the knowledge necessary to reduce informational asymmetry. See Chayes \& Chayes, supra note 1, at 293-99 (describing effect of reliance on in-house counsel on relationships between corporate clients and elite law firms); Rosen, supra note 2, at 481-90; infra Part III.B.2.

135. See Carrie Menkel-Meadow, Culture Clash in the Quality of Life in the Law: Changes in the Economics, Diversification and Organization of Lawyering, 44 CASE W. RES. L. REV. 621, 630-31 (1994) (noting "fierce competition" among law firms for the acquisition and retention of clients and the frequent use of seminars and other low-key forms of advertising to attract business); Wilkins, supra note 129 , at 884 (noting that corporations now routinely shop for lawyers by holding "beauty contests" in which firms compete for important work).

136. See Rosen, supra note 2, at 485 (noting that outside law firms frequently "cede strategic control" to in-house legal departments); Wilkins, supra note 129, at 887 (noting that corporate clients now exercise significant control over every facet of law firms' internal operations by approving staffing choices, reviewing documents, requiring detailed bills, and making substantive legal decisions). In this way, corporate clients are blurring the distinction between 
Moreover, and perhaps most significantly, most clients no longer rely on a single attorney or law firm to service all of their legal needs. While corporations once found it efficient to invest in long-term relationships with individual law firms, it is now common for corporate clients to strategically chose counsel for discrete needs, based on practice specialties, costs, and other pragmatic factors. ${ }^{137}$ Thus, while the existence of an absolute attorney loyalty obligation enables clients to demand a personal commitment from those whom they view as "their" lawyers, fewer and fewer corporate clients maintain any degree of loyalty, in the common sense of the word, to the attorneys they choose. ${ }^{138}$

In all of these ways, the power imbalance that arguably characterizes the attorneyclient relationship has become distorted by the increased commercialization of modern legal practice and the growing sophistication of those entities seeking legal services. ${ }^{139}$ In such an environment it is reasonable to ask whether the model of unilateral loyalty in which the attorney must completely set aside all interests deemed adverse to the client is actually necessary to ensure quality performance, or more importantly whether it is proper in a situation involving conflict between the lawyer and the client. If the attorney is bound to a duty of absolute loyalty to the client that trumps even her personal interests, should not the client bear some responsibility in protecting those interests over which it exercises significant control?

\section{Characterizing In-House Counsel: Specialized \\ Professional or Business Employee?}

These questions resonate all the more powerfully in the in-house counsel context, where the attorney-client relationship is complicated, not only by the sophistication of the client and general trends in corporate legal practice, but by the overlay of additional duties and responsibilities attendant to an employment relationship. For

decisions about the aims and purposes of legal representation, which have always been considered the prerogative of the client, and the means by which those ends are accomplished, which has traditionally fallen within the discretion of the attorney. See MODEL RULES, supra note 10, Rule $1.2 \mathrm{cmt}$. ("Scope of Representation").

137. See Chayes \& Chayes, supra note 1, at 294 n.50 (noting that according to a 1980 s study only $10 \%$ of large companies spent more than half their outside counsel fees with one firm) (citing ARTHUR YOUNG SURVEY, supra note 1); Rosen, supra note 2, at 489 (observing that the emerging pattern of law firm retention is a movement "away from bilateral monopolies toward a competitive market in which alternative suppliers are plentiful and may be hired either on a spot contract or an employment basis"). In addition, the selective reliance on individual attorneys with expertise in particular areas is replacing retention of firms that formerly served as full-service general counsel to corporate clients. See Liggio, supra note 2, at 1210 .

138. Indeed clients may even take advantage of the ethical regime designed to protect them by parceling out their work to a large number of firms so as to later invoke the categorical prohibition against those law firms bringing suit against them. See Thomas D. Morgan, Suing a Current Client, 9 GEO. J. LEGAL ETHICS 1157, 1162 (1996).

139. See Wilkins, supra note 129 , at 882 (noting that the agency model that defines lawyerclient relationships is "premised on a set of interconnecting factual assumptions about client vulnerability ... [that] fail to capture the complex power relationship between contemporary corporate clients and their outside counsel"). 
purposes of accounting for the context in which workplace discrimination problems arise, the in-house attorney-corporate client relationship may be characterized by a decrease in the control normally associated with the role and position of the attorney and, at the same time, by an increase in the assumption of responsibilities not traditionally associated with lawyer's work. ${ }^{140}$ In this way, the in-house attorney assumes what can be considered the burdens of employment, so that entitlement to the benefits of that status seems appropriate. ${ }^{141}$

Unlike their law firm counterparts, in-house counsel are particularly vulnerable in the event of a disruption of their employment relationship. In-house attorneys have no ability to hedge against a potential loss of income by developing a diversified client base, but instead owe their livelihood and professional futures to a single clientemployer ${ }^{142}$ At the same time, in-house counsel are subject, like other employees, to the pay scales, personnel policies, and other workplace constraints imposed unilaterally by their client-employer. In this way, in-house counsel's economic dependence on the corporate client more closely approximates the relationship that exists between other upper-level employees and their employer than that which exists between a client and its outside counsel. ${ }^{143}$ To whatever extent the sacrifice-or-

140. Much has been written about the nature of in-house practice and its development in the last several decades. For a discussion of the nature of in-house practice, the historical role of in-house counsel, and recent trends in the development of corporate legal departments, see SALLY GUNZ, THE NEW CORPORATE COUNSEL (1992); Chayes \& Chayes, supra note 1, at 27993; Liggio, supra note 2, at 1201-22; Rosen, supra note 2, at 503-25.

141. Recognition of the differences in the responsibilities of in-house attorneys versus outside lawyers necessarily generates concern over the professional status of in-house attorneys. Resistance to this approach has chiefly argued that creating what might be deemed exceptions to the ethics rules will lead to a regime in which in-house counsel are considered second-rate professionals in relation to their elite law firm counterparts. See Rhode, supra note 122. Such fears are based largely on historical ideas about what types of attorneys traditionally entered in-house positions and the type of work they performed, concepts which are now being supplanted by a surge in the visibility and professional power of in-house attorneys. See Geoffrey C. Hazard, Jr., Ethical Dilemmas of Corporate Counsel, 46 EMORY L.J. 101 1, 1012 (1997) (noting that the "second-class citizenship" previously assigned to in-house attorneys has now ceased as a result of changes in corporate clients' reliance on in-house legal departments and changes in legal practice generally); see also supra note 2 . As these trends in corporate legal practices continue, it becomes increasingly unsound as well as unnecessary to refuse to recognize legitimate differences in the nature of in-house lawyers' work and responsibilities that will affect the moral calculus under which these lawyers operate.

142. As the California Supreme Court explained in General Dynamics Corp. v. Superior Court, 876 P.2d 487, 491 (Cal. 1994):

Unlike the law firm partner, who typically possesses a significant measure of economic independence ... derived from a multiple client base, the economic fate of in-house attorneys is tied directly to a single employer. . . . [F]rom an economic standpoint, the dependence of in-house counsel is indistinguishable from that of other corporate managers or senior executives who also owe their Id. livelihoods and career goals and satisfaction to a single organizational employer.

143. It should be noted that the in-house attorney who finds herself in a dispute with her employer stands not only to lose her job, she risks the possibility of being professionally 
withdraw regime may be justified in other contexts, the idea that the attorney possesses significantly greater bargaining power than her client is certainly inapposite here. ${ }^{144}$

The issue is not merely one of financial dependence, however, but also one of parity of treatment vis-à-vis other upper level employees. In-house counsel are expected to be immersed in the corporation that they serve; they share and participate in its risks, successes, projections, and goals. ${ }^{145}$ This integration is reflected in the work that in-house lawyers do. Companies do not retain in-house counsel solely as substitutes for outside counsel, but as members of the "team" responsible for running the business. ${ }^{146}$ In addition to the usual work relating to the management of specific legal matters, in-house counsel participate frequently in long and short term strategic planning and almost always are responsible for prevention and compliance programming and the supervision of outside counsel. ${ }^{147}$ With respect to their corporate planning functions, in-house counsel's role goes beyond legal risk analysis to consultation and participation in the executive decisionmaking process through membership on planning committees and senior management councils, and through informal contact with chief officers and financial personnel. ${ }^{148}$ In-house counsel are viewed as contributing specialized knowledge of the business as well as legal expertise. ${ }^{149}$ In this way they perform as executives invested with significant responsibility for the success and direction of the company.

With respect to their oversight and compliance responsibilities, in-house counsel act much like managers of both the internal and external resources of the company. As lawyers practicing preventative law, in-house counsel are charged with the education of operating personnel whose duties determine corporate compliance: Counsel must disseminate information about applicable law, identify risky business practices and propose changes, respond appropriately to company violations, and monitor employee behavior for continued compliance. ${ }^{150}$ As the employees primarily

blacklisted in the corporate-legal community in the event that her termination occurs on bad terms. See Hazard, Jr., supra note 141, at 1015.

144. See Rosen, supra note 2, at 492-93 (comparing economic dependence of in-house and outside counsel).

145. See Liggio, supra note 2, at 1206 (describing such attorneys as the "new breed" of corporate counsel); Howard B. Miller, Law Risk Management and the General Counsel, 46 EMORY L.J. 1223, 1223 (1997) (describing general counsel as combined risk analyzers and information managers).

146. See Brotman \& Ogden, supra note 6, at 34; Hazard, Jr., supra note 141 , at 1017 ; see also Rosen, supra note 2, at 526-27 (describing in-house counsel as "'institutional personnel" empowered by their corporations to be involved in formulating, influencing and implementing corporate goals and commitments").

147. See Chayes \& Chayes, supra note 1, at 280-93 (describing typical functions of in-house lawyers beyond assumption of work otherwise performed by outside counsel); see also Rosen, supra note 2 , at 504, 510-24.

148. See Chayes \& Chayes, supra note 1 , at $282-83$ (describing trend toward formal integration of in-house counsel into corporate planning process).

149. See Brotman \& Ogden, supra note 6, at 34-35; Daly, supra note 1, at 1060-61.

150. See Chayes \& Chayes, supra note 1, 284-87 (describing role of in-house attorney in developing programmatic prevention plans). See generally Richard S. Gruner, General Counsel in an Era of Compliance Programs and Corporate Self-Policing, 46 EMORY L.J. 
responsible for retained outside counsel, in-house counsel create and oversee the company's contracts for external legal services. Their responsibilities may include identification of work to be assigned externally, selection of appropriate outside counsel, negotiation and review of fees, bills, and projected budgets, participation in strategic decisions related to outside legal matters, and performance oversight. ${ }^{151}$ Inhouse counsel effectively manage the company's internal legal compliance and its use of external legal services as other divisions manage cash resources and product quality. ${ }^{152}$

Thus, the role that in-house counsel assumes on behalf of the client is larger in several respects than that of an outside attomey. ${ }^{153}$ This expanded image of in-house counsel should have significant implications on the standard for ethical compliance in the face of a challenge to individual rights. To the extent the work performed by in-house lawyers resembles and even overlaps with the work of other managers and executives, who are unquestionably within the reach of Title VII, it is reasonable to treat in-house lawyers comparably. All employees, including upper level managers and executives, are entitled to exercise Title VII rights, including the right to bring suit while employed, without fear of retaliation. Such suits obviously may strain the relationship between employer and employee and indeed, in the case of upper-level employees, may be perceived by the employer as a breach of loyalty. However, such suits have nonetheless been deemed protected unless or until they have a tangible effect on performance that constitutes a nonpretextual basis for termination. Allowing the concept of "loyalty" to preclude a claim when grounded in ethical principles appears no more legitimate than an equivalent sanction based on employer sentiment, which is clearly in the teeth of the statutory prohibition.

More importantly, the expanded role of in-house counsel and the integration of the position within the company itself calls for an increased investment on the part of the individual attorney that rightfully requires a concomitant increase in client responsibility. The acceptance of an in-house counsel position entails various sacrifices, including the loss of financial security and professional autonomy that come with the ability to maintain an independent practice. It is the client who reaps the benefits of these sacrifices in terms of its consistent access to the legal advice and other resources provided by the in-house attorney at a fixed cost and the increased quality of services obtained resulting from the attorney's commitment to and integration within the company. Given that the client gains the benefit of having a

1113,1141-63 (1997) (discussing role of general counsel in corporate compliance generally).

151. See Chayes \& Chayes, supra note 1, at 289-93.

152. See Gruner, supra note 150, at 1152; see also Rosen, supra note 2, at 524 (noting that in-house lawyers practicing preventative law act as managers drawing on various resources made available to them).

153. Of course outside law firms frequently take on work for corporate clients that relates to business planning, compliance, and preventative programming in addition to traditional work involving the resolution of particular legal matters. However, the work of outside firms is necessarily less customized than that of in-house counsel and does not require the lawyer's complete personal investment in the success of the company. Because of the nature of the inhouse counsel's work and her proximity to the client, companies are likely to expect a greater degree of loyalty and commitment from in-house attomeys than from outside firms. See Wilkins, supra note 129 , at $886-87$. 
multi-faceted employee over an outside attorney, it is logical to expect the client to assume the resulting burden associated with the attorney's change in status, that is, a full commitment to compliance with the applicable employment laws.

\section{Justifying and Limiting the Application of a Modified Ethical Calculus}

For all of these reasons, an implicit acceptance of the idea that ethical constraints preclude employed in-house counsel from exercising the full extent of their rights as employees is unsuited to the contextual reality in which discrimination claims arise. A modified ethical regime, based on the concept of shared responsibility between the in-house attorney and the corporate client, is therefore appropriate.

The necessary limits of such an approach, however, should here be identified in anticipation of legitimate objections to altering the existing balance of responsibilities in which the lawyer's ethical duties are considered absolute. Recognition of the attorney's right to the full protection of Title VII does not open the floodgates to a regime in which the external personal interests of lawyers are perceived as equivalent or superior to the needs of clients. The basis for adopting a modification in the discrimination context lies in the nature of the in-house attorney's interest as one rooted in the employment relationship and for which the client is responsible. ${ }^{154}$ Nor does granting the attorney the benefit of the law imply that in-house attorneys subject to discrimination will in all cases pursue litigation against their corporate employers while employed, a situation that would admittedly create severe difficulties for both parties. While simultaneous litigation may result in some circumstances, ${ }^{155}$ the purpose of recalibrating the ethical scheme is to enable attorneys to respond to discrimination effectively. By recognizing the in-house attorney's entitlement to job protection and creating a means by which she can seek redress in court, the law assures in-house counsel the leverage she needs to bring internal complaints through the proper channels, insist that responsive action is taken, and, if necessary, negotiate favorable terms of severance in resolution of these types of disputes. ${ }^{156}$

In this way, the argument in favor of modifying the governing ethical precepts is fundamentally about encouraging compliance with the discrimination laws. The rigid enforcement of ethical rules in the in-house counsel context allows corporations to discriminate with relative impunity ${ }^{157}$ where the employee in question is an attorney. By removing the employer's ability to escape liability by relying on the attorney's special status, the new regime would force employers to behave proactively in

154. This distinguishes the "adverse" interest at stake in this problem from competing financial interests or business pursuits of the attorney.

155. See infra Part III.B. (discussing the extent to which the rules of professional ethics would constrain in-house counsel in pursuing such a suit).

156. See Weaver, supra note 1 , at 1050 (favoring internal resolution of in-house counsel discrimination disputes).

157. In the absence of any protection from retaliation, in-house counsel would be discouraged from engaging in protected conduct. However, in-house counsel would be permitted to pursue a claim provided she resigned or had been terminated by the client. See supra note 19. 
preventing and responding to discrimination complaints in order to avoid lengthy and potentially disruptive legal battles with its employed counsel.

\section{STRIKING A DOCTRINAL BALANCE}

Having identified the need for an alternative approach to professional ethics in the context of discrimination suits by in-house counsel, the question remains how to strike an appropriate balance between the interests of the attorney and the client in light of existing law. The following subpart examines two judicial attempts to resolve disputes between in-house attorneys and their employers arising in analogous areas of law. Building on these efforts, the subpart then offers a reinterpretation of the relevant ethical rules that would permit an in-house attorney in certain circumstances to fully exercise her Title VII rights, while at the same time recognizing and accommodating concerns regarding the diligence and trustworthiness of in-house counsel from the perspective of the employer.

\section{A. The Quest for an Integrated Approach}

While courts and commentators have begun to consider greater role-based distinctions in delineating the ethical obligations of in-house counsel, ${ }^{158}$ a consistent framework for application remains elusive. ${ }^{159}$ The challenge, particularly in the context of discrimination against in-house counsel, lies in balancing not only the diverse professional obligations of the attorney with the needs and demands of the client, but also in determining how to incorporate the individual rights and personal entitlements of the person employed as the attorney. Two areas in which ethical conflicts have arisen between in-house counsel and their client-employers and in

158. See, e.g., General Dynamics Corp. v. Superior Court, 876 P.2d 487, 491-92 (Cal. 1994) (explaining functional differences between in-house and outside counsel in recognizing inhouse attorney's right to sue for common law wrongful discharge); see also infra Parts III.A.1, III.A.2. See generally Schneyer, supra note 1, at 454-57 (describing development of "role morality" as means of approaching ethical questions).

159. The absence of ethical rules or standards to guide lawyers in a wide array of modern situational conflicts arising as a result of the increasingly diversified role of the attomey has been criticized by scholars. See, e.g., Carrie Menkel-Meadow, The Silences of the Restatement of the Law Governing Lawyers: Lawyering as Only Adversary Practice, 10 GEO. J. LEGAL ETHICs 631, 635-38 (1997) (critiquing absence of ethical rules to govern lawyers engaged as mediators or third-party neutrals). See generally David A. Kessler, Professional Asphyxiation: Why the Legal Profession Is Gasping for Breath, 10 GEO. J. LEGAL ETHICS 455, 457 (1997) (noting the "distinct lack of an inherent moral framework within current ethical codes and rules"). With respect to in-house counsel, while there are a growing number of reported cases addressing in-house attorney employment disputes, these decisions tend to reach fact-specific results which, while useful in providing underlying support for a modified ethical regime, fail to offer a consistent doctrinal approach that may easily be imported to the discrimination context. See General Dynamics, 876 P.2d at 502-05; Santa Clara County Council Attorneys Ass'n v. Woodside, 869 P.2d 1142, 1154-55 (Cal. 1994); infra Part IV.A.1-2. 
which varying degrees of ethical accommodations have been made to benefit inhouse counsel serve as useful illustrations of this development.

\section{Balancing the Interests of Society: Common Law Retaliatory Discharge Claims}

One area which has invited significant judicial and scholarly attention to the issue of role-based differences in the application of ethical precepts to in-house attorneys is the problem of common law wrongful discharge claims by terminated corporate counsel. ${ }^{160}$ Initially, courts refused to permit terminated counsel to pursue wrongful discharge claims on grounds that attorneys, unlike regular employees, owe special fiduciary duties to their client-employers and can be terminated at any time. ${ }^{161}$ Thus, in Balla v. Gambro, for instance, in which an in-house attorney was fired for objecting to his client's sale of defective dialyzers, the Supreme Court of Illinois held that no tort action was warranted because the applicable state ethics rules required the aggrieved attorney either to report his client's activities or to withdraw from representation. ${ }^{162}$ Citing the "unique" nature of the attorney-client relationship, the court opined that permitting the tort claim would critically harm the absolute trust and confidence between lawyer and client, and concluded that public safety was adequately protected by the attorney's ethical obligation to disclose the misconduct. ${ }^{163}$ Much like the Fifth Circuit in Douglass v. DynMcDermott Petroleum Operations Co. ${ }^{164}$ these cases turn to the ethical rules as the exclusive source of law for regulating conflict between in-house counsel and the client-employer. In so doing, they place traditional and largely under-explored concepts of professional behavior above the common law principles applicable to employees, ${ }^{165}$ viewing the ideals of

160. Sounding either in tort or contract, wrongful discharge claims generally allege that the client-employer unlawfully terminated the attorney-employee either for refusing to engage in unlawful conduct or for reporting unlawful conduct of the client to an outside authority. In the tort context, these claims are generally articulated within the public policy exception to the atwill doctrine. See, e.g., Willy v. Coastal Corp., 647 F. Supp. 116 (S.D. Tex. 1986), rev'd on other grounds, 855 F.2d 1160 (5th Cir. 1988); General Dynamics, 876 P.2d 487; Balla v. Gambro, Inc., 584N.E.2d 104 (Ill. 1991). Contract-based claims are less frequent; they usually allege that the employment agreement contained an implied understanding that the attorney would behave lawfully. See, e.g., Mourad v. Automobile Club Ins. Ass'n, 465 N.W.2d 395 (Mich. Ct. App. 1991). See generally Daniel S. Reynolds, Wrongful Discharge of Employed Counsel, 1 GEO. J. LEGAL ETHICS 553 (1988) (summarizing nature of the wrongful discharge claim and noting distinctions between tort-based and contract-based approaches).

161. See Balla, 584 N.E.2d at 109; Herbster v. North Am. Co. for Life \& Health Ins., 501 N.E.2d 343, 347 (Ill. App. Ct. 1986); see also Willy, 647 F. Supp. at 118.

162. 584 N.E.2d at 110.

163. Id. at 108-09; see also Willy, 647 F. Supp. at 118 (finding that applicability of mandatory withdrawal regime under ethics rules obviated need for common law protection under public policy exception); Herbster, 501 N.E.2d at 346 (citing special position attorneys occupy in society in failing to extend tort of wrongful discharge to in-house attorneys).

164. 144 F.3d 364 (5th Cir. 1998).

165. For the most part these cases merely recite the basic premise that the attorney-client relationship is one of exceptional trust and confidence. See, e.g., Herbster, 501 N.E.2d at 346. 
the profession and the status of employee as seemingly incompatible. ${ }^{166}$

More recently, other courts have adopted a different and more nuanced approach, permitting in-house attorneys to sue for wrongful discharge under certain circumstances. ${ }^{167}$ In General Dynamics, for instance, the California Supreme Court recognized many of the differences that distinguish in-house attorneys from their law firm counterparts, including the long-term relationship between client and in-house counsel; the larger role assumed by in-house counsel, which encompasses managerial decisionmaking as well as the provision of standard legal services; and the financial dependence of in-house counsel on a single client-employer. ${ }^{168}$ The court at the same time recognized the need to uphold the ethical principles that safeguard trust and confidence in the attorney-client relationship. ${ }^{169}$ It therefore called for a balanced approach that would permit an in-house attorney to pursue a wrongful discharge claim in situations where confidences could be safeguarded. Thus the court held that the plaintiff-in-house attorney could proceed with his wrongful discharge claim provided either that confidential information would not be revealed by his suit or that any disclosure would fall within the exceptions to the applicable state ethics rules. ${ }^{170}$

The articulation of an approach sanctioning in-house counsel wrongful discharge claims offers a useful starting point for considering discrimination claims given these decisions' recognition of the legitimate differences in the duties of in-house attorneys versus those of outside counsel and the constraints implicit in the employer-employee relationship. Indeed, the extension of the right to pursue wrongful discharge claims offers the individual attorney a powerful means to ensure against the personal and financial repercussions she might suffer as a result of an ethical conflict. Yet the recognition of a personal remedy for the attorney in this context is largely fortuitous. The California opinion and comparable cases evoke a more integrated view of inhouse counsel as both attorney and employee, but ultimately hinge the availability of the wrongful discharge cause of action on in-house counsel's technical compliance

166. See Reynolds, supra note 160 , at 566 (noting that the cases involving wrongful discharge presume that the lawyer's professional role is incompatible with employee rights without attempting to locate the lawyer's claim within otherwise applicable common law). The Balla decision and the handful of cases reaching similar results have spawned a plethora of critical scholarship. See, e.g., Giesel, supra note 46; Stephen Gillers, Protecting Lawyers Who Just Say No, 5 GA. ST. U.L. Rev. 1 (1988); Nancy Kubasek et al., The Social Obligation of Corporate Counsel: A Communitarian Justification for Allowing In-House Counsel To Sue for Retaliatory Discharge, 11 GEO. J. LEGAL ETHCS 665 (1998).

167. Most notably the California Supreme Court in General Dynamics Corp. v. Superior Court, 876 P.2d 487 (Cal. 1994). See also GTE Prods. Corp. v. Stewart, 653 N.E.2d 161 (Mass. 1995); Nordling v. Northern States Power Co., 478 N.W.2d 498 (Minn. 1991); cf. Mourad v. Automobile Club Ins. Ass'n, 465 N.W.2d 395 (Mich. Ct. App. 1991) (recognizing contract-based claim); Parker v. M \& T Chems., Inc., 566 A.2d 215 (N.J. Super. Ct. App. Div. 1989).

168. 876 P.2d at 491.

169. See id. at 492.

170. See id. at 503-05; see also GTE, 653 N.E.2d at 167 (holding that claim will be permitted to proceed only if it can be proved without any violation of attorney's obligation to respect client confidences and secrets); Nordling, 478 N.W.2d at 502; cf. Wieder v. Skala, 609 N.E.2d 105, 109 (N.Y. 1992); Willy v. Coastal States Management Co., 939 S.W.2d 193 (Tex. Ct. App. 1996). 
with the confidentiality rules. ${ }^{171}$ Thus, courts appear to balance the competing demands of the profession and the individual attorney, but in reality hold in-house counsel to the same universal standards imposed throughout the profession. ${ }^{172}$

This result follows necessarily from the focus of these decisions, which is not on accommodating the interests of the plaintiff but on enforcing the attorney's obligations to society. The tort of wrongful discharge is designed to guard against violations of recognized public policies. ${ }^{173}$ This goal is accomplished by enabling employees to report or refuse to participate in their employer's unlawful behavior without fear of reprisal and by imposing the risk of tort liability on those employers who engage in conduct that endangers the public. Thus, the purpose of the cause of action is not to provide a remedy for loss of employment or to safeguard any right to job security, but rather to protect society by protecting the employee who acts in society's interest. In the case of in-house counsel, the attorney has a professional duty to the public, ${ }^{174}$ in addition to any personal compunction to act on society's behalf, and is thus forced to choose between her obligations to her client and her obligation to third parties. ${ }^{175}$ For this reason, courts generally frame the in-house counsel wrongful discharge problem as a conflict between the zealous advocacy and social calling aspects of the legal profession. ${ }^{176}$ In this context, the allowance of the cause of action reflects not a recognition of in-house counsel's right to job protection, but rather a means of encouraging in-house counsel to abide by their ethical obligations to the public despite their financial and professional dependance on their corporate employers. ${ }^{177}$ For these reasons, the wrongful discharge cases provide useful support

\section{See General Dynamics, 876 P.2d at 493.}

172. In so doing, the courts largely erode the cause of action that they recognize by placing the attorney in the impossible position of being able to file a claim without being able to offer any evidence to support it. See Willy, 939 S.W.2d at 200 (recognizing availability of cause of action for in-house attorney but finding plaintiff could not proceed because confidential information would be revealed during suit).

173. See LINDEMANN \& GROSSMAN, supra note 26, at 1016 (noting that "tort cause of action exists where a discharge is 'against public policy and affects a duty which inures to the benefit of the public at large rather than to a particular employer or employee'") (quoting Foley v. Interactive Data Corp., 765 P.2d 373, 379 (Cal. 1988)) .

174. See MODEL RULES, supra note 10, pmbl. ("A lawyer is . . a public citizen having special responsibility for the quality of justice."). A lawyer's ethical obligations to the client thus may be limited by the attorney's competing obligations to third parties and the judicial system. See id. Rule 1.6(b)(1) (exception to confidentiality rule exists where disclosure is necessary to prevent client from committing crime or injury to third party); id. Rule 3.3(b) (requirement of honesty before tribunal requires disclosure even if information is otherwise protected by confidentiality rule); see also infra Part I.B.2.

175. See General Dynamics, 876 P.2d at 498 (noting that attorney more than other employees is likely to face ethical conflicts because lawyer's work is affected with public interest and concluding that it is precisely because of special ethical obligations of in-house counsel to act in society's interest that judicial remedy is appropriate).

176. See Giesel, supra note 46, at 562-74.

177. See General Dynamics, 876 P.2d at 497-98 (stating that provision of legal remedy to attorney was not in recognition of right to job protection, but because of societal interests in preserving health and safety and encouraging law-abiding behavior); see also Giesel, supra note 46, at 550-57; Gillers, supra note 166, at 5-9; Kubasek et al., supra note 166, at 685-88. 
for role-based analysis of the in-house counsel discrimination problem, but fail to offer an underlying theoretical approach that recognizes and accounts for attorneys' competing personal interests. ${ }^{178}$

\section{The Perception/Performance Distinction: Santa Clara v. Woodside}

In comparison to the common law wrongful discharge scenario, the problem of discrimination against employed in-house counsel in contravention of Title VII presents an even greater challenge to the application of ethical rules. Whereas the conflict in common law wrongful discharge cases implicates the attorney's competing professional allegiances to the client and the public, the conflict in discrimination cases arising under Title VII stems from an assertion of individual rights that are neither sanctioned nor acknowledged in the existing scheme of professional ethics. In asserting her position, the in-house attorney faced with workplace discrimination sets her personal interests above and against those of her client, thus violating fundamental principles of client fidelity.

In this way the discrimination problem is primarily concerned with the ethical duty of loyalty and the conflict of interest rules. In the common law wrongful discharge context, the legal battle between the parties necessarily occurs after the attorney-client (employee-employer) relationship has been severed by the client. Thus, the primary ethical issue in those disputes involves the revelation of allegedly confidential information by the attorney in pursuit of her claim. ${ }^{179}$ While similar concerns will arise as a result of the filing of a federal discrimination charge, the more pressing and ultimately more troubling issues are the immediate strain placed on the relationship as a result of the in-house attorney's simultaneous pursuit of adverse personal interests and the limits on the client's autonomy to respond to this perceived violation of trust by terminating the relationship. Unlike the common law wrongful discharge context, there appears to be little room, even on a theoretical level, for insistence on full compliance with existing ethical rules while sanctioning the attorney's pursuit of her claim.

An approach that seems to account for these distinctions and accept the idea of an ethical compromise can be found in the treatment of the analogous problem of

178. That is not to say that common law wrongful discharge claims cannot be cast as an issue of client responsibility for in-house attorney's ability to perform her work freely and within the bounds of ethics. Cf. Mourad v. Automobile Club Ins. Ass'n, 465 N.W. 2d 395, 400 (Mich. Ct. App. 1991) (determining that every client-attorney employment contract contains implied term that attorney will abide by the applicable rules of professional conduct in recognizing cause of action for attorney's wrongful discharge). However, the existing case law and scholarship has favored an approach that locates the problem in the tension between the attorney's responsibilities to the client and society. See supra note 174.

179. The conflict-of-interests rules would, of course, still be relevant to an analysis of the wrongful discharge problem. Terminated in-house counsel could have a successive conflict-ofinterest problem based on her former representation of the defendant. See MODEL RULES, supra note 10, Rule 1.9. However, the existing cases have not raised this issue and the duty of confidentiality remains the primary concern. 
collective bargaining rights of unionized attorneys. ${ }^{180}$ In Santa Clara, for instance, the California Supreme Court created a limited exception to the termination at will principle under state ethics rules for government attorneys seeking to assert collective bargaining rights while employed. ${ }^{181}$ There, a labor organization representing attorneys in the county counsel's office sought a declaration that its members were not required to resign from their positions prior to the union's initiation of a suit against the county employer for failure to bargain in good faith under state law. ${ }^{182}$ Recognizing the need for a "realistic accommodation" between employed attorneys' professional obligations and their rights as employees, the court proposed a "pragmatic approach," in which conformity to ethical precepts would be judged not on perceived antagonism between lawyer and client, but on whether representation was actually compromised by the attorneys' activities. ${ }^{183}$ The court held that initiation of litigation while employed does not itself violate ethical precepts, ${ }^{184}$ provided the attorney does not "overstep[] ethical boundaries" by failing to represent the client "faithfully, competently and confidentially." state collective bargaining law created an exception to the general rule that a client may terminate its attorney at will and that the county-employer could not discharge its attorneys for participating in union activities. ${ }^{186}$ At the same time, the court held that the county should be afforded great flexibility in restructuring its office and potentially reassigning certain legal matters in order to protect confidential information pertaining to labor relations issues. ${ }^{187}$

The treatment of collective bargaining rights provides a useful model for reconciling the ethical rules with the rights conferred by Title VII. Santa Clara

180. See Santa Clara County Counsel Attorneys Ass'n v. Woodside, 869 P.2d 1142 (Cal. 1994); Chiles v. State Employees Attorneys Guild, 734 So. 2d 1030 (Fla. 1999).

181. 869 P.2d at 1157-58.

182. See id. at 1146 . The question whether an attorney is permitted under the rules of ethics to join a labor organization, while originally subject to some debate, has been answered in the affirmative by the ABA Committee on Ethics and Professional Responsibility. See ABA Comm. on Ethics and Professional Responsibility, Informal Op. 986 (1967). See generally Santa Clara, 869 P.2d at 1155-56. Issues involving attorney collective bargaining rights generally arise, however, under state law as the applicable federal legislation excludes supervisory personnel from its definition of covered employees. See id. at 1147-48; see also 29 U.S.C. § 152(3) (1994).

183. Santa Clara, 869 P.2d at 1157.

184. The court initially determined that the California Rules of Professional Conduct, which are slightly less prohibitive than the Model Rules on this point, did not explicitly prohibit the attorneys from bringing suit while employed. See id. Whereas the Model Rules's simultaneous representation rule deals with both personal interests adverse to a current client as well as the representation of clients with interests adverse to a current client, the California rule refers only to the representation of other clients. Compare MODEL RULES, supra note 10, Rule 1.7(b), with CALIFORNIA RULES OF PROFESSIONAL CONDUCT Rule 3-310(C)(3) (1989).

185. Santa Clara, 869 P.2d at 1157; see also Chiles, 734 So. 2d at 1037; cf. Baird v. Cutler, 883 F. Supp. 591 (D. Utah 1995) (recognizing need for different application of loyalty principles to employed attorneys in acknowledging attorney's right to bring free speech claims against city employer).

186. See Santa Clara, 869 P.2d at 635.

187. See id. at 635-36. 
demonstrates both a forthright recognition of the tension implicit in the dual roles of attorney and employee and a willingness to forge a doctrinal compromise to achieve an accommodation of employer and attorney interests. The decision does not completely resolve all aspects of the problem; ${ }^{188}$ however, its approach is unique in its ability to view the individual interests of the attorney-plaintiffs apart from but simultaneously with their professional obligations. Rather than accept the notion that pursuit of individual interests necessarily impairs the ability to perform professionally, which would justify an absolute clientright to terminate counsel based on perceived disloyalty, the court identifies and protects what is ultimately at stake: the client's ability to insist on the unfettered performance of quality legal work by its chosen counsel. Thus, the attorney's right to pursue individual rights is sanctioned unless and until it has an actual adverse effect on the attorney's ability to represent her client.

\section{B. Revisiting the Rules}

The distinction identified in the collective bargaining context between the perception of disloyalty and the effect of competing interests on performance offers a potential source of doctrinal compromise in the context of the ethics/Title VII conflict. The perception/performance distinction argues for a less emphatic response than that offered by the rule-exalting approach in Douglass in terms of analyzing ethical behavior. At the same time, recognition of this distinction can do justice to the needs of the client by identifying situations in which the lawyer's competing personal interest renders professional loyalty impossible. A proposal for incorporating this distinction in interpreting the ethics rules follows.

\section{From Ethereal Concepts to Actual Conflicts: \\ Defining Loyalty in the Context of the Work That In-House Lawyers Do}

With respect to the initial question whether an in-house attorney may, within the bounds of ethics, bring suit while retaining her position as an attorney, a modest reinterpretation of Model Rule 1.7 is in order. ${ }^{189}$ In the context of a Title VII discrimination claim by employed counsel, the conflict of interest rule should be read, not to place a categorical ban on proceedings against the client-employer, but rather to prohibit suits where an actual conflict affecting the attorney's performance is

188. In particular, the court fails to sufficiently tackle the issue of confidentiality, cursorily concluding that confidential information would not be implicated by the attorneys' suit. Santa Clara, 869 P.2d at 1158 n.9.

189. This subpart should not be read to suggest that an in-house attorney should consider litigation the primary means of responding to employment discrimination. Efforts to reach an internal resolution of such a dispute would be less disruptive and could be more successful. However, in the absence of legal recognition of an in-house attorney's right to avail herself of the full protection of the statute while employed, the attorney's ability to successfully implement alternative dispute resolution techniques to address her concerns is seriously compromised. See generally supra Part III.C. 
unavoidable. ${ }^{190}$

In developing such an analysis, it is first necessary to properly locate the problem within the framework of the current rule. Specifically, conflicts resulting from discrimination against in-house counsel should be evaluated, not under part (a) of Rule 1.7, the "direct adversity" section, but rather under an adjusted reading of part (b) of the Rule, the "materially limiting" section. ${ }^{191}$ Rule 1.7(a) prohibits an attorney from "represen[ting] a client if the representation . . . will be directly adverse to another client,"192 thus placing a clear prohibition on simultaneous representation of competing interests in the absence of proper client consent. ${ }^{193}$ While the initiation of a suit by in-house counsel reasonably constitutes litigation against an existing client, it is not adverse representation as described in Rule 1.7(a) because the attorney brings the simultaneous suit in her personal capacity rather than as an attorney, that is, she does not "represent" a competing interest. Treating the potential conflict of interests as a Rule 1.7(a) problem wrongly conflates in-house counsel's personal and professional roles.

Rule 1.7(b), on the other hand, explicitly contemplates conflicts stemming from competing personal interests, as distinct from those resulting from multiple professional allegiances. Rule $1.7(\mathrm{~b})$ prohibits an attorney from engaging in representation that may be materially limited by "the lawyer's own interests."194 This portion of the rule, rather than establishing an outright bar, prohibits only those representations that will be adversely affected by the attorney's outside interests. Thus the existence of a conflict precluding continued employment by in-house counsel is not and should not be assumed based solely on the existence of a claim, ${ }^{195}$

190. The idea of narrowing the scope of Rule 1.7 to permit greater flexibility to practitioners seeking to represent what would otherwise be considered adverse interests has been proposed in other contexts, particularly with respect to problems involving corporate subsidiaries. See Morgan, supra note 138, at 1179-80 (advocating for case-specific approach to determining existence of impermissible conflict that would take into account whether reasonable client would perceive breach of loyalty under circumstances and whether there is a credible basis for believing attorney will be tempted to perform less diligently for one client because of representation of other).

191. Compare MODEL RULEs, supra note 10, Rule 1.7(a), with id. Rule 1.7(b). It has been argued in other contexts that the language contained in part (a) of the rule is mere surplusage on the rule articulated in part (b). See Morgan, supra note 138, at 1182-83.

192. MODEL RULES, supra note 10, Rule 1.7(a).

193. An assumption of this Article is that a corporate employer would not "consent" to the in-house attorney's pursuit of her own claim while continuing her representation of the corporate client.

194. MODEL RULES, supra note 10, Rule 1.7(b).

195. The presumption that the filing of a claim alone creates an impermissible conflict harkens to the appearance of impropriety standard for identifying conflicts set forth in the Model Code of Professional Responsibility and abandoned in the Model Rules. See MODEL CODE, supra note 47, Canon 9 (entitled "A Lawyer Should Avoid Even the Appearance of Professional Impropriety"); see also In re Coordinated Pretrial Proceedings in Petroleum Prods. Antitrust Litig., 658 F.2d 1355, 1360-61 (9th Cir. 1981) (finding that court may disqualify attorneys based solely upon Canon 9 prohibition against appearance of inappropriate representation where impropriety is clear and recognizable as such by reasonable persons). 
but rather should be considered in light of the circumstances giving rise to the claim and the nature of the attorney's work for the client.

As the comments to Rule 1.7 indicate, the critical question in determining whether an impermissible conflict exists should be whether the conflict will materially interfere with the lawyer's independent professional judgment in considering alternatives on behalf of the client. ${ }^{196}$ In the in-house counsel context, the ability to bring the discrimination claim should depend on whether the work that the in-house attorney performs for the company is at all related to her claim, so that she might be tempted to forego possible defenses and strategies on behalf of her client in order to advantage herself and her legal position. ${ }^{197}$ The determination should be fact-based, taking into account the realities of the attorney's practice as well as her own perception of the conflict. ${ }^{198}$ The automatic assumption that there has been a breach of loyalty, simply as a result of the filing of a charge and irrespective of its effect on performance, should not be a basis for subjecting an attorney to discipline if the attorney made a reasoned determination that she could perform despite her claim. ${ }^{199}$

From the point of view of ethical compliance then, an attorney should be justified in filing a claim while employed under these circumstances, despite the absence of consent. ${ }^{200}$ However, at common law and under the Model Rules, the client would still

196. See MODEL RULES, supra note 10, Rule $1.7 \mathrm{cmt} .4$.

197. Thus, an in-house attorney whose responsibilities included resolution of personnel matters would not be permitted to bring a claim, while an attorney whose work involved solely the negotiation of leases, procurement contracts, or other discrete transactional work might be able to do so.

198. Not every suit by an attorney engaged in matters other than employment issues should necessarily be considered permissible. If the attorney suspects she will perform her work less diligently as a result of personal feelings about her employer stemming from her claim, she would be obligated to resign.

199. Essentially this determination is akin to that which must be made under Rule 1.7(b)(1) in order to bring an adverse representation outside the scope of the rule. Cf. MODEL RULES, supra note 10, Rule 1.7(b)(1) (requiring that attorney reasonably believe the representation of existing client will not be impaired by representation of adverse interest). Thus, the difference between the application of Rule 1.7(b) as contemplated by the Model Rules and that proposed here is effectively the removal of the requirement of client consent set forth in Rule 1.7(b)(2). See infra text accompanying note 200 .

200. In this way, the proposal locates the ability to identify and judge potential conflicts in the in-house attorney rather than in the corporate client. Cf. MODEL RULES, supra note 10 , Rule $1.7 \mathrm{cmt} .15$ (noting that the "[resolution of] questions of conflict of interest is primarily the responsibility of the lawyer undertaking the representation" rather than an issue to be debated by competing parties in litigation). In general, the Model Rules contemplate that professional standards will be enforced through self-regulation and, where appropriate, the disciplinary process; the affirmative, strategic exploitation of perceived violations by clients is therefore frowned upon. See id. pmbl. (stating that Model Rules are not intended to form a basis for civil liability and noting that "the purpose of the Rules can be subverted when they are invoked by opposing parties as procedural weapons"); see also Hizey v. Carpenter, 830 P.2d 646, 650-51 (Wash. 1992) (en banc) (rejecting litigant's attempt to introduce breach of ethical rules as basis for asserting breach of standard of care in proving legal malpractice claim). But see Lazy Seven Coal Sales, Inc. v. Stone \& Hinds, P.C., 813 S.W.2d 400, 405 (Tenn. 1991) (recognizing rule violation as providing limited guidance on breach of standard 
be permitted to terminate the attorney irrespective of whether the claim is considered an ethical breach. The right to select and terminate counsel must not be subjugated to the attorney's individual rights, but should be constrained to restrict the employer from violating federal law. In this respect, the existing Title VII doctrine concerning the limits of protected conduct and the burden of proof structure applicable to retaliation claims should suffice to prevent retaliation while ensuring that corporate employers retain the ability to terminate counsel in whom they have legitimately lost trust. In keeping with the provision, the client-employer should not be permitted to terminate an in-house attorney who files a claim simply on the basis of her status as an attorney or on ethereal concepts of client loyalty; such justifications are the semantic equivalents of basing a decision to terminate on the filing of the claim alone, which is expressly prohibited. However, the employer is and should be free to terminate counsel for actual disloyalty, either in the form of a rule violation, ${ }^{201}$ inadequate performance, ${ }^{202}$ unprofessional behavior, ${ }^{203}$ or any other nonpretextual reason.

Thus, both the attorney's obligation to comply with ethical precepts and the right of the client to terminate counsel at will should be evaluated based on an understanding of loyalty grounded in the reality, rather than the imagery, of what attorneys are expected to do. Rather than penalize the individual based on her status as an attorney, the approach offered here sanctions the pursuit of personal interests, provided the attorney can reasonably fulfil her role as an attorney with the degree of competence and dedication that the rules require.

\section{Contextualizing the Confidentiality Question: Rethinking the Scope of Protected Information}

Permitting suit under the ethics rules and constraining the employer's right to terminate counsel does not resolve the conflict posed by in-house counsel's ongoing duty of confidentiality. Because the Model Rules broadly prohibit an attorney from revealing any information related to a client, strict application of the ethical rules

of care for legal malpractice claim).

201. This would include a violation of the revised reading of Rule $1.7(b)$ proposed here, as where an in-house attorney with responsibility for personnel matters brings suit despite the objective likelihood that her work will be compromised. This result would be consistent with certain court decisions regarding Title VII claims by non-attorney employees charged with personnel responsibilities. See, e.g., Smith v. Singer Co., 650 F.2d 214, 217 (9th Cir. 1981) (finding defendant's termination of director of industrial relations charged with achieving federal affirmative action compliance following plaintiff's discrimination complaint did not constitute unlawful retaliation). But see, e.g., Francoeur v. Corroon \& Black Co., 552 F. Supp. 403, 412 (S.D.N.Y. 1982) (finding nothing in plaintiff's position as personnel manager or her behavior in filing charge that would permit employer to lawfully terminate her).

202. In other words, where the in-house attorney's representation of the corporate client is actually impaired by her pursuit of the discrimination claim. The employer's assertion of performance-based grounds for termination must be factual in nature and not a mere recital of perceived inability to perform.

203. As where the in-house attorney engages in extra-oppositional behavior that provides an independent basis for termination. See supra text accompanying notes 40-41. 
would prevent the in-house attorney from testifying ${ }^{204}$ in support of her claim or even revealing information about her claim to her attorney. ${ }^{205}$ Recognition of in-house counsel's entitlement to Title VII protection therefore requires a reconsideration of the confidentiality rule in addition to the modifications in the conflict of interest rule previously described.

Existing elements of the rule and its exceptions argue for a more relaxed interpretation of the prohibition in the in-house counsel discrimination context. Part (b) of Rule 1.6, which contains limited exceptions to the duty of confidentiality, expressly permits an attorney to reveal confidences in a dispute between the attorney and the client. ${ }^{206}$ The comments to the rule refer to only two scenarios involving this exception, malpractice claims and fee disputes, ${ }^{207}$ and the exception has often been viewed as limited to those contexts. ${ }^{208}$ However, the language of the exception refers broadly to an attorney's use of information to "establish a claim or defense" in a "controversy between the lawyer and the client." suggest the exception may be relied upon to alleviate the duty to maintain confidences where an in-house attorney wishes to bring a discrimination claim

204. The attorney's attempt to testify could be prohibited by the attorney-client privilege as well. However, since the prohibition embodied in the confidentiality rules is substantially broader than the privilege, this subpart will focus on the treatment of the former. For a general discussion of the distinctions between the privilege and the duty of confidentiality, see generally X Corp. v. Doe, 805 F. Supp. 1298, 1304-08 (E.D. Va. 1992).

205. See MODEL RULES, supra note 10, Rule 1.6; discussion supra Part I.B.2 .

206. See MODEL RULES, supra note 10, Rule 1.6(b)(2).

207. See id. Rule $1.6 \mathrm{cmt}$. 19.

208. See Weaver, supra note 121, at 521 n.143.

209. The full text of the exception provides:

(b) A lawyer may reveal such information to the extent the lawyer reasonably believes necessary:

(2) to establish a claim or defense on behalf of the lawyer in a controversy between the lawyer and the client, to establish a defense to a criminal charge or civil claim against the lawyer based upon conduct in which the client was involved, or to respond to allegations in any proceeding concerning the lawyer's representation of the client.

MODEL RULES, supra note 10, Rule 1.6(b). This version of the text clearly expands the scope of the predecessor section in the Model Code which limited the exception to the two cited examples: "A lawyer may reveal ... confidences or secrets necessary to establish or collect his fee or to defend himself against an accusation of wrongful conduct." MODEL CODE, supra note 195, Rule 4-101(C)(4); see also MODEL RULES OF PROFESSIONAL CONDUCT Rule 1.6 Model Code Comparison (1983) ("Paragraph (b)(2) enlarges the exception to include disclosure of information relating to claims by the lawyer other than for the lawyer's fee; for example, recovery of property from the client."). What is unclear, however, is how broad the expanded exception is intended to reach and, hence, whether it applies in an attorney-client employment dispute. See Kachmar v. Sungard Data Sys. Inc., 109 F.3d 173, 179-80 (3d. Cir. 1997) (finding exceptions to Pennsylvania version of Rule $1.6(b)(2)$ inconclusive on whether terminated attorney may reveal confidences in pursuit of Title VII retaliation claim); WOLFRAM, supra note $47, \S 6.7 .8 \mathrm{n} .3$ ("The point of the broader language in ... Model Rule [1.6] is unclear."). See generally Weaver, supra note 121, at 520 n.143 (comparing clauses of Rule 1.6(b)). 
against her client. ${ }^{210}$

One need not rely, however, on the breadth of the language or risk an interpretation that permits a lesser degree of compliance in any dispute between lawyer and client in order to read the existing exception as embracing discrimination suits. The claims expressly excepted in the comments, fee and malpractice matters, are those that implicate the attorney's ability to practice and earn a living, interests that the Model Rules recognize and see the need to accommodate in defining ethical behavior. ${ }^{211}$ That fee and malpractice matters are the only claims identified makes sense in light of what the ethical rules currently understand to be the extent of the client's responsibility to ensure that the attorney's personal interests are satisfied and protected. This Article has argued, however, that at least in the in-house counsel context, the notion of client responsibility must be expanded to account for the loss of control and increase in rights associated with the attorney's status as an employee. If in recognizing these differences more extensive obligations are imposed on the client, including the responsibility to ensure that the attorney performs her duties free from unlawful discrimination, it is rational to recognize a related confidentiality exception that will permit the attorney to utilize the necessary resources to enforce those responsibilities where the client fails to uphold them. ${ }^{212}$

Recognizing a theoretical and doctrinal basis for an extended exception, however, does not tell attorneys what information may be revealed or reassure clients that their interests in confidentiality will be protected. In general, when relying on a confidentiality exception, an attorney may reveal information only to the extent she reasonably believes necessary to advance the purpose giving rise to the disclosure. ${ }^{213}$ Because it would be permissible in the discrimination context for in-house counsel to continue to perform as an attorney under the amended loyalty regime previously discussed, ${ }^{214}$ more specific and perhaps more restrictive limitations are appropriate.

A means of striking a balance between the client's interest in non-disclosure and the attorney's need to pursue her claim lies in the rule's own definition of confidential

210. See Philadelphia Bar Assoc. Professional Guidance Comm., Op. 99-6 (Aug. 1999) (citing Pennsylvania "claim or defense" exception to confidentiality rule in advising that former in-house attorney may make limited use of confidential or privileged information in pursuit of wrongful discharge claim); Weaver, supra note 121, at 535-36 (advocating for similar interpretation of $1.6(b)(2)$ exception).

211. See MODEL RULES, supra note 10, pmbl. (recognizing that "[v]irtually all difficult ethical problems arise from conflict between a lawyer's responsibilities to clients, to the legal system and to the lawyer's own interest in remaining an upright person while earning a satisfactory living").

212. In the same way, the justification for expanding the exception may be phrased directly in terms of the modification to the loyalty obligation previously proposed. See discussion infra Part III.B.1. Such an articulation recognizes that the duty of confidentiality is an aspect of the duty of loyalty in that the prohibition is on betraying the client by revealing confidences. See Patterson, supra note 47, at 914-45 (tracing the development of the duty of confidentiality as a separate ethical responsibility). If the ability to bring a claim is excepted from the loyalty obligation, so to should be the use of information to support it.

213. See MODEL RULES, supra note 10, Rule 1.6(b); id. Rule $1.6 \mathrm{cmt}$. 18 ("[D]isclosure should be no greater than the lawyer reasonably believes is necessary to vindicate innocence.).

214. See supra Part III.B.1. 
information as information "relat[ed] to the representation."215 Since in-house counsel are hired as attorneys to represent the company, one might argue that any information related to the client or received by the attorney on the job is within the scope of the rule. However, such an interpretation wrongly supposes that everything in-house counsel does for or with the client is in the nature of legal representation. In-house counsel also acquire information and make observations related to their own employment as distinct from their work function. An understanding of what information may be revealed in a discrimination case should be based on this distinction.

While it may not be easy in every case to distinguish between information related to the attorney's employment by the company as opposed to her representation of the company as a client, that difficulty is hardly unique to the in-house counsel discrimination context. ${ }^{216}$ Certain guidelines can be identified based on the evidence that in-house counsel is likely to use to pursue such a claim. An in-house attorney should not be permitted to reveal information regarding the employer's handling of fair employment practices issues, which the attorney acquired through her legal work or by virtue of her presence in the corporate legal department. This would encompass such things as information about confidential client hiring practices, affirmative action and personnel policies not available to other employees, past or pending discrimination complaints or other employment-related claims, and company procedures for responding to employee complaints. Such information should not be disclosed because it would clearly be related to the attorney's representation of the client. ${ }^{217}$ On the other hand, information about the in-house attorney's experience in the workplace, which ultimately forms the subject of the lawsuit, should not be considered confidential because such information pertains to the in-house attorney's treatment as an employee. Such information would include, among other things, information about perceived instances of discrimination or harassment, discussions about the attorney's performance, any complaints made by the attorney, and any responses by the company. ${ }^{218}$ To the extent it is unclear whether information derives

215. MODEL RULES, supra note 10, Rule 1.6(a).

216. The problem of separating the in-house attorney's multiple functions has been particularly difficult with respect to client attempts to invoke the attorney-client privilege. See generally Giesel, supra note 8, at 1190-1203 (describing court confusion in attempting to distinguish between communications related to in-house counsel's legal representation and those pertaining to business matters). The difficulty of making such determinations should not be a reason for rejecting the distinction. Cf. Kachmar v. Sungard Data Sys., Inc., 109 F.3d 173, 181-82 (3d Cir. 1997) (refusing to bar former in-house attorney's Title VII suit based on claims of attorney-client privilege noting that "there may be a fine but relevant line to draw between the fact that ... [plaintiff in-house attorney] took positions on certain legal issues involving ... [company] policies, and the substance of her legal opinions").

217. The majority of this information would also be protected by the attorney-client privilege. See X Corp. v. Doe, 805 F. Supp. 1298, 1305 (E.D. Va. 1992) (privilege applies where "the party invoking the privilege consulted an attorney for the purpose of securing a legal opinion or services and in connection with that consultation communicated information intended to be kept confidential").

218. Cf. Kachmar, $109 \mathrm{~F} .3 \mathrm{~d}$ at 181 ("[I]t is difficult to see how statements made to ... [plaintiff-in-house attorney] and other evidence offered in relation to her own employment and 
from in-house counsel's employment relationship or her representation of the company, ${ }_{2}^{219}$ in-hquse counsel should err on the side of ethics and not reveal the information, leaving her attorney to obtain relevant discovery without her assistance. ${ }^{220}$ In all cases, the client-employer would have the ability to seek protective measures from the court to ensure that confidential information is not disclosed outside the proceeding. ${ }^{221}$

Thus, as the existing exceptions to the confidentiality rule suggest, an attorney's obligation to maintain client confidences must be limited to some degree by her need to protect her own interests. By its nature, information sought to be presented by an in-house attorney in a discrimination suit will be information that the client-employer wishes to keep confidential. Once an attorney's right to initiate a claim is recognized as being within the bounds of her ethical duties, the employer should not be permitted to hamstring her effort to pursue the claim based solely on her status as an attorney. Rather than adhering strictly to the broad interpretation of confidential information, the approach discussed here proposes a more literal reading of Rule 1.6 that accounts for in-house counsel's employment relationship with the company and permits the attorney to reveal and freely testify about the treatment she experienced that forms the substance of her claim.

her own prospects in the company would implicate the attorney-client privilege."); Breckinridge v. Bristol-Myers Co., 624 F. Supp. 79, 82 (S.D. Ind. 1985) (noting that conversations between in-house counsel and client-employer regarding the former's retirement plans were "conversations between an employer and an employee who happened to be an attorney" and not subject to attorney-client privilege).

219. For instance, an in-house attorney might have information about personnel policies and practices that is within the knowledge of nonlegal personnel, or it may be commonly known among company employees that a certain employee has previously been accused of harassment. Cf. Kachmar, 109 F.3d at 181 (finding it "questionable whether information that was generally observable to ... [plaintiff in-house attorney] as an employee of the company, such as her observations concerning the lack of women in a ... [company] subsidiary, would implicate the ... [attomey-client] privilege").

220. While the in-house attorney could not reveal or testify about such information, nothing would prohibit the attorney representing in-house counsel from obtaining relevant discovery and introducing information into evidence through other witnesses. However, the attorney representing in-house counsel might have separate ethical obligations not to request or utilize confidential client information improperly revealed by in-house counsel. See MODEL RULES, supra note 10, Rule 8.3(a) ("A lawyer having knowledge that another lawyer has committed a violation of the [Model Rules] that raises a substantial question as to the lawyer's honesty, trustworthiness or fitness as a lawyer in other respects, shall inform the appropriate professional authority.").

221. See, e.g., Kachmar, 109 F.3d at 182 (recommending use of equitable measures including "sealing and protective orders, limited admissibility of evidence, restrictions on use of testimony in successive proceedings, and ... in camera proceedings" in attempt to balance need for protection of sensitive client information with right of former in-house attorney to maintain discrimination suit) (omission added) (quoting General Dynamics Corp. v. Superior Court, 876 P.2d 487, 504 (Cal. 1994)). 


\section{CONCLUSION}

An exploration of the conflict between the Model Rules of Professional Conduct and Title VII of the Civil Rights Act in the case of in-house counsel uncovers fundamental questions about the limits of the duty of loyalty and the extent to which individual interests should be considered in delineating the scope of professional responsibility generally. This Article has sought to deconstruct governing principles of ethics that would preclude an exercise of individual rights by in-house counsel by locating the existing rule scheme in an image of the professional relationship in which the attorney wields substantial power over a vulnerable client. This image and the rules that flow from it are ill-suited to the realities of modern legal practice and fail to account for in-house counsel's legitimate need for job protection in a situation where she acts and is treated as much as an employee as an attorney. The Article has advocated instead for an alternative allocation of responsibility between attorney and client in which the client's use and retention of in-house counsel, who will assume professional obligations toward the client, create a concomitant obligation on the part of the client to maintain and protect the attorney's ability to perform in the workplace. Whether the concept of a balance of responsibilities between attorney and client might apply equally in other contexts may well be a subject for further speculation and research. At least in the discrimination situation, such an approach is administerially feasible and morally justified as a means both of protecting in-house attorneys and encouraging corporate compliance with the federal discrimination laws. 